\title{
Dilatação dos confins: caminhos, vilas e cidades na formação da Capitania de São Paulo (1532-1822)
}

\section{Beatriz Piccolotto Siqueira Bueno ${ }^{1}$}

RESUMO: Este ensaio analisa a formação da rede urbana das capitanias de São Vicente e Santo Amaro, depois unidas na Capitania de São Paulo. Discute o processo de apropriação do sertão, a pulsação e dilatação dos confins ao sabor dos deslocamentos humanos e de interesses políticos. Interpreta o papel de capelas, freguesias, vilas e cidades no controle e produção de territórios metropolitanos em solos ultramarinos.

PalaVRAS-ChAVE: História da Urbanização. Capitania de São Vicente. Capitania de Santo Amaro. Capitania de São Paulo. Séculos XVI-XVIII. Rede urbana.

ABSTRACT: This essay analyzes the development of urban networks in the Captaincies of São Vicente and Santo Amaro, later merged into the Captaincy of São Paulo. It discusses the process of appropriation of the sertão (backcountry), the commotion and expansion beyond the confines to the tune of population movements and political interests. The paper also interprets the role of chapels, parishes, villages and towns in initiatives to create and control metropolitan areas on overseas soil.

KEYWORDS: History of urbanization. Captaincy of São Vicente. Captaincy of Santo Amaro. Captaincy of São Paulo. 16th-1 8th centuries. Urban networks.

Sobre o conceito de território e suas vinculações com a rede urbana

Território e espaço não são noções equivalentes ${ }^{2}$. $\bigcirc$ território, com contornos e limites precisos é uma categoria histórica, construída socialmente. Para além das fronteiras naturais, a fronteira política é sempre uma linha abstrata e convencionada por alguns. Às zonas interiorizadas dava-se o nome de "sertão"
1. Docente da Faculdade de Arquitetura e Urbanismo da Universidade de São Paulo. E-mail: <beatrizbueno@terra. com.br>.

2. Sobre o conceito de território, consultar Beatriz P. S. Bueno (2003, p. 482-487). 
3. Cf. R. Bluteau (v. 4, 1712, p. 219).

4. "Conquistas - as terras, Províncias, Reynos conquistados." Cf. Idem (v. 2, 1712, p. 471).

5. "Domínios - bens que se possuem \& de que se pode usar, \& dispor como proprios; possessiones parte de um Imperio". "Império - região muyto ampla, dominada de hum Principe..." Cf. Idem (v. 4, 1712)

6. “'Territoire: rare jusqu'au XVIIe s.; répandu au XVIIIe s.', dit le Littré [...] Le mot est donc d'invention récente, si l'on veut bien prendre l'échelle du temps historique. Pourtant les juristes ont fait du territoire une catégorie quasi universelle: le territoire, lit-on encore aujourd'hui dans bien des manuels de droit consituionnel, est un élément constitutif de l'Etat. Le territoire est ainsi devenu l'expression juridique d'une donnée faussement naturelle. Les juristes ont réussi a confondre territoire et espace, et a naturaliser par ce procédé l'Etat bourgeois. Pourtant, le territoire n'a rien de spontané. Si on se penche sur sa découverte par 1 'Etat absolutiste et sur sa production para l'administration d'alors, on doit bien considérer son caractère relatif et contingent. Le territoire n'est pas cette donnée à peu près indiscutable parce que géographique que la doctrine juridique a installée à la base de son analyse de 1 'Etat. Il est un des premiers appareils d'Etat que l'administration a su engendrer et reproduire, avant que la Révolution bourgeoise n'en tire le maximum de profit. L'analyse présentée ici n'est rien d'autre qu'une découverte des modes de production de ce territoire faussement innocent; l'histoire d'une invention que nous avons fini par prendre pour notre environnement naturel et spontané". Cf. P. Alliès (1980).
- "região apartada do mar, \& por todas as partes metida entre terras" - cabendo à ação humana dilatar-the os "confins" terra contígua com outra". Na documentação oficial, não por acaso, os termos "conquista"4 e "domínio" 5 aparecem como sinônimos de "colonia" e sempre vinculados à ação humana. Impérios, reinos, conquistas, províncias, capitanias, comarcas, bispados eram divisões territoriais convencionadas e historicamente desenhadas de acordo com a natureza das relações sociais em jogo. $O$ estabelecimento oficial das fronteiras jurídicas resultava de atos deliberados e acordados politicamente.

Conceito de invenção recente, difundido a partir do século XVIII, o "território"b tornou-se um elemento constitutivo dos Estados Dinásticos em processo de formação. Embora tendamos a naturalizá-lo, trata-se de uma categoria nada espontânea. Neologismo assimilado em Portugal, território aparece no dicionário etimológico de Raphael Bluteau, em 1712, como "o espaço de terra, nos contornos, \& jurisdição de huã cidade"7. Ora, as "cidades" 8 nas Ordenações do Reino de Portugal eram as "capitais" - "cabeça, princípio, \& fonte, donde outras cousas se encerram" -, ou seja, os prolongamentos do aparelho estatal, braços da Coroa, no reino ou nas distantes conquistas ultramarinas. Estar nos contornos e sob a jurisdição de uma "cidade" significava ser parte de um reino ou império. Não por acaso, apenas a Coroa tinha a prerrogativa de fundar "cidades" em seus territórios. No Brasil-Colônia, as instâncias de poder organizavam-se hierarquicamente em instituições irradiadas a partir das "cidades reais". Seguindo padrões portugueses, as instâncias administrativa, jurídica e eclesiástica sobrepunham seus territórios no espaço. As vilas tinham papel hierarquicamente inferior às "cidades", mas superior às capelas e freguesias. Todas, igualmente, eram tentáculos metropolitanos na distante "Conquista", cumprindo papéis distintos na lógica da rede urbana.

A rede eclesiástica ${ }^{9}$ precedia a rede civil e, em termos jurídicos, ficava submetida a ela. Através da lgreja, de suas instâncias de base, umbilicalmente ligadas às do próprio Estado, a institucionalização de povoados dispersos dava-se, inicialmente, pela oficialização de sua ermida. A elevação de uma comunidade ao estatuto de capela curada significava a ascensão de uma região inóspita a núcleo reconhecido pela lgreja e também a garantia de visita de um pároco (cura). Tanto o acesso à assistência religiosa como o reconhecimento de fato e de direito perante a Igreja e o Estado motivavam a solicitação junto ao bispado. A subsequente elevação à condição de freguesia garantia o acesso ao batismo, ao casamento, ao amparo dos enfermos, aos sacramentos, aos registros de nascimento, de matrimônio, de óbito, com todas suas implicações jurídicas e sociais. Para além do acesso ao rito litúrgico, a elevação de uma capela a freguesia implicava em usufruto da formalidade civil ${ }^{10}$. Na freguesia, a antiga ermida merecia nomenclatura de matriz, ganhando a construção de uma sacristia anexa. Para lá se dirigia a população das capelas curadas vizinhas, para registro de nascimentos, matrimônios e óbitos. No entanto, em caso de auxílio jurídico, ambas - capela ou freguesia -, recorriam à vila de cujo "termo" 11 eram parte. 
A elevação ao estatuto de vila significava acesso a uma outra categoria institucional e à autonomia política e administrativa:

Crescendo sua expressão populacional, econômica e edificada, terá aumentado sua aspiração a outra categoria institucional, a outro tipo de reconhecimento por parte da sociedade organizada, em meio à divisão territorial estabelecida pelos poderes constituídos, enfim, por parte do Estado. A sua aspiração seguinte seria constituir não mais um embrião oficial, a célula menor eclesiástica e administrativa, porém algo mais, que não se referia apenas ao tamanho ou à ascensão gradual hierárquica: seria alcançar a autonomia política e administrativa, seria passar a constituir sede de um município, passar a zelar por si mesma, aglomeração, e por um território próprio correspondente que the seria designado, seu termo. A autonomia municipal colocaria o povoado, quem sabe a antiga freguesia ou paróquia, como unidade autônoma dentro do Estado, fosse o reino como uma de suas colônias, fosse esta como o país já independente. $\bigcirc$ povoado se tornaria a sede de uma área territorial bem definida, entre outras mais antigas ou a serem criadas, termos municipais na ocasião definidos ou redefinidos. Ganhava então, para todos os efeitos, um lugar ao sol ${ }^{12}$.

A solicitação de elevação ao estatuto de capela e freguesia era feita pela população junto ao bispado, que, por ocasião das Visitações do bispo às capitanias, também podia elevar, a seu bel-prazer, esse ou aquele a tais categorias. Já a condição de vila era concedida pelo capitão-donatário ou por Ordem Régia. Em solo urbano, a elevação à categoria de vila implicava na concomitante edificação de uma casa de câmara e cadeia e de um pelourinho fronteiro a ela. Símbolos da autonomia municipal e sede da administração, os vereadores e juízes cumpriam, na câmara, funções legislativas, executivas e judiciárias. Ao Conselho Municipal cabia zelar pelo patrimônio público laí incluso o rossio), bem como conceder os terrenos urbanos (datas) e rurais (sesmarias) a particulares. "Lugares da vida segura e conversável" (como mencionadas na documentação oficial quinhentista), embora diminutas em tamanho e população, as vilas foram polos culturais, políticos e comerciais em solo colonial.

Os diversos contornos assumidos pelo atual estado de São Paulo oscilaram ao sabor de interesses oficiais e extraoficiais, materializando-se numa intricada rede urbana, viária e fluvial, viabilizada graças à sábia simbiose com os indígenas. Malgrado os avanços da historiografia recente ${ }^{13}$, ainda temos pouco a dizer, do ponto de vista da história da urbanização, acerca dessa simbiótica relação entre indígenas e portugueses na produção do território do Brasil meridional. Tampouco dispomos de levantamentos sobre a rede eclesiástica - de capelas, freguesias - e de aldeias indígenas e jesuíticas em solo paulista, o que muito elucidaria esse lento processo de apropriação do sertão.

A cartografia representa a simbiose entre indígenas e lusitanos, sobretudo nos topônimos referentes à natureza e à rede urbana. Abundam nomes indígenas mesclados a nomes lusitanos, propiciando a visualização de algo que ainda carece de sistematização e interpretação pela historiografia. Neste artigo, ênfase especial será dada às vilas e cidades, em detrimento da rede de capelas, freguesias, aldeamentos indígenas e jesuíticos pré-existentes. Subjaz aqui o convite
7. Cf. R. Bluteau (v. 8,1712 , p. 128).

8. Idem, v. 2, p. 125.

9. M. Marx, 1991, p. 17-30

10. Idem, p. 18-19.

11. Território municipal.

12. Cf. M. Marx (1991, p. 52).

13. Ver J. M. Monteiro (1994); M. C. Scatamacchia $(1990 ; 2005)$; M. C. Scatamacchia e D. P. Uchôa (1993); R. Gianessella (2008). 
14. Nessa nova linha de investigação, encontramos apenas a dissertação de mestrado de R. Gianessella (2008).

15. Segundo o Mapa Corograpbico da Capitania de São Paulo, datado de 1791, do engenheiro militar Antônio Rodrigues Montezinhos, os limites da Capitania de São Paulo eram: com Minas Gerais, a serra da Mantiqueira e o rio Sapucaí; com Goiás, o rio Grande, o rio Pardo e o rio Claro; com o Rio Grande de São Pedro, o rio Pelotas e o rio Uruguai; com Mato Grosso, o rio Paraná; com o mar, a oriente, a Capitania do Rio de Janeiro (na parte setentrional) e a Capitania de Santa Catarina (na meridional).

16. Cf. M. A de Casal (1976, p. 97).

17. Ver A. de Azevedo (1956); e N. G. Reis Filho (2001, p. 85-88).

18. Às vilas soma-se um conjunto expressivo de capelas e freguesias, entre as quais, no século XVIII, despontam São Luis e Santo Antonio de Paraitinga (1773), Piracicaba, Wotucatu, São José da Marinha de Ararapira, N. S. da Conceição da Lage (entre Iguape e Cananéia) e Santo Antonio da Lapa do Registro de Curitiba (Lapa-PR).

19. Consultar: MUNICÍPIOS e distritos do estado de São Paulo (1995); QUADRO do desmembramento territorialadministrativo dos municípios paulistas (1995). para estudos futuros e a expectativa de que a cartografia apresentada forneça pistas para novas linhas de investigação sobre a história da urbanização ${ }^{14}$.

A seriação dos mapas permite constatar que, em fins do século XVIII, os contornos da Capitania de São Paulo mostravam-se muito distintos dos originais e dos atuais ${ }^{15}$. O Pe. Manuel Aires de Casal assim a descreveu em 1817 :

Confina ao norte com a [Capitania] de Minas Gerais, de que é separada pela Serra da Mantiqueira, e com a de Goiás de que é dividida pelo Rio Grande; ao sul com a de São Pedro, da qual é separada pelo Rio Pelotas; ao ocidente com o Rio Paraná, que a divide das províncias de Goiás e Mato Grosso; a oriente tem o mar oceano, e as províncias do Rio de Janeiro na parte setentrional, e a de Santa Catarina na meridional"16.

A Capitania de São Paulo formou-se a partir da união das antigas capitanias de São Vicente e Santo Amaro, concedidas respectivamente aos irmãos Martim Afonso e Pero Lopes de Souza, em reconhecimento aos bons serviços prestados à Coroa em 1532, quando vieram ao Brasil. Os limites geográficos da Capitania de S. Vicente estendiam-se desde a barra do rio São Francisco do Sul à itha de Santo Amaro (atual Guarujá); os da Capitania de Santo Amaro, desde a itha de mesmo nome até a enseada de Ubatuba (Figuras 1-3). Obviamente, essas 150 léguas (inicialmente) concedidas ao longo da costa sul da América portuguesa foram alargadas em todos os sentidos durante os três primeiros séculos, decorrendo de um processo de interiorização e expansão territorial de seus habitantes. Incorporadas, em 1709, por compra, aos bens da Coroa, durante o reinado de D. João V, foram denominadas Capitania de São Paulo e Minas de Ouro, tendo por sede administrativa a vila de mesmo nome, elevada em 1711 à categoria de Cidade.

Em fins do século XVIII, a Capitania englobava o atual estado do Paraná, parte de Santa Catarina e do Rio Grande do Sul, apresentando um conjunto de cerca de 34 núcleos ${ }^{17}$ elevados à categoria de vila ${ }^{18}$, e uma cidade ${ }^{19}$, a saber:

\begin{tabular}{|l|l|}
\hline 1532 - & São Vicente; \\
\hline 1545 - & Vila Porto de Santos; \\
\hline 1560 - & São Paulo dos Campos de Piratininga (elevada à categoria de Cidade em 171 1); \\
\hline 1561 - & Nossa Senhora da Conceição de Itanhaém; \\
\hline 1577 - & Nossa Senhora das Neves de lguape; \\
\hline 1600 - & São João Batista de Cananeia; \\
\hline 1611 - & Santana de Mojimirim (Mogi das Cruzes); \\
\hline 1625 - & Santana de Parnaíba; \\
\hline 1636 - & São Sebastião; \\
\hline
\end{tabular}




\begin{tabular}{|c|c|}
\hline $1637-$ & Exaltação da Santa Cruz do Salvador de Ubatuba; \\
\hline $1645-$ & São Francisco das Chagas de Taubaté; \\
\hline $1653-$ & Nossa Senhora da Conceição do Rio Paraíba (Jacareí); \\
\hline $1649-$ & Nossa Senhora do Rosário de Paranaguá; \\
\hline $1655-$ & Nossa Senhora do Desterro do Campo Alegre de Jundiaí; \\
\hline $1651-$ & Santo Antônio de Guaratinguetá; \\
\hline $1657-$ & Nossa Senhora de Candelária do Outu Guaçu (ltu); \\
\hline $1661-$ & Nossa Senhora da Ponte de Sorocaba; \\
\hline $1693-$ & Nossa Senhora da Luz dos Pinhais de Curitiba; \\
\hline $1705-$ & Nossa Senhora do Bom Sucesso de Pindamonhangaba; \\
\hline $1767-$ & São José do Paraíba (São José dos Campos); \\
\hline $1769-$ & Itapeva da Faxina (Itapeva); \\
\hline $1769-$ & São João Batista do Atibaia; \\
\hline $1769-$ & São José do Mogy-Mirim; \\
\hline $1770-$ & Sabaúna; \\
\hline $1771-$ & Nossa Senhora dos Prazeres de Itapetininga \\
\hline $1771-$ & Santo António das Minas do Apiai (Apiaí); \\
\hline $1771-$ & Vila Nova de São Luis de Guaratuba (Guaratuba); \\
\hline $1774-$ & Nossa Senhora dos Prazeres de Lages (Lajes-SC); \\
\hline $1785-$ & Cunha (antiga Freguesia do Facão); \\
\hline $1788-$ & Nossa Senhora da Piedade de Lorena; \\
\hline $1797-$ & $\begin{array}{l}\text { São Carlos (antiga freguesia de N. S. da Conceição das Campinas do Mato } \\
\text { Grosso de Jundiaí) (Campinas); }\end{array}$ \\
\hline $1797-$ & Porto Feliz (antiga freguesia de Araritaguaba); \\
\hline $1797-$ & Nova Bragança (Bragança Paulista); \\
\hline $1797-$ & Antonina; \\
\hline $1798-$ & Castro (antiga freguesia de S. Ana do lapó - PR) \\
\hline
\end{tabular}

20. Ver pranchas anexas ao Quadro do desmembramento territorial-administrativo dos municípios paulistas (1995).

Os núcleos foram formados a partir de quatro vilas - São Vicente, São Paulo, Mogi das Cruzes e Taubaté -, conforme o Quadro do Desmembramento Territorial-Administrativo dos Municípios Paulistas ${ }^{20}$ : 


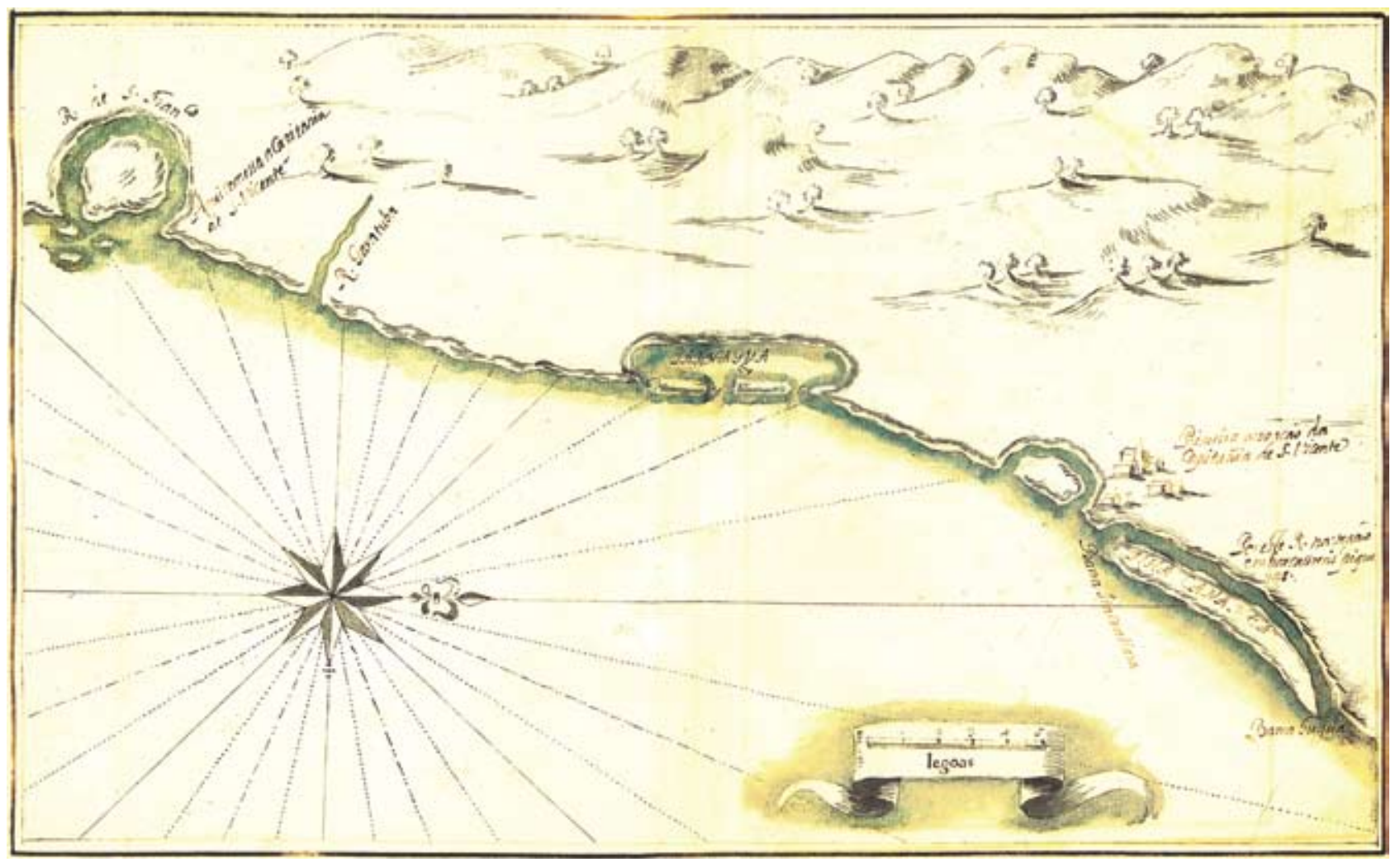

Figura 1 - João Teixeira Albernaz I, Descripção de todo o Maritimo da Terra de S. Crus chamado vulgarmente o Brazil. [c. 1640]. Coleção Brasiliana/Fundação Estudar. Acervo da Pinacoteca do Estado, São Paulo. Fonte: "Descripção..."(2003). 


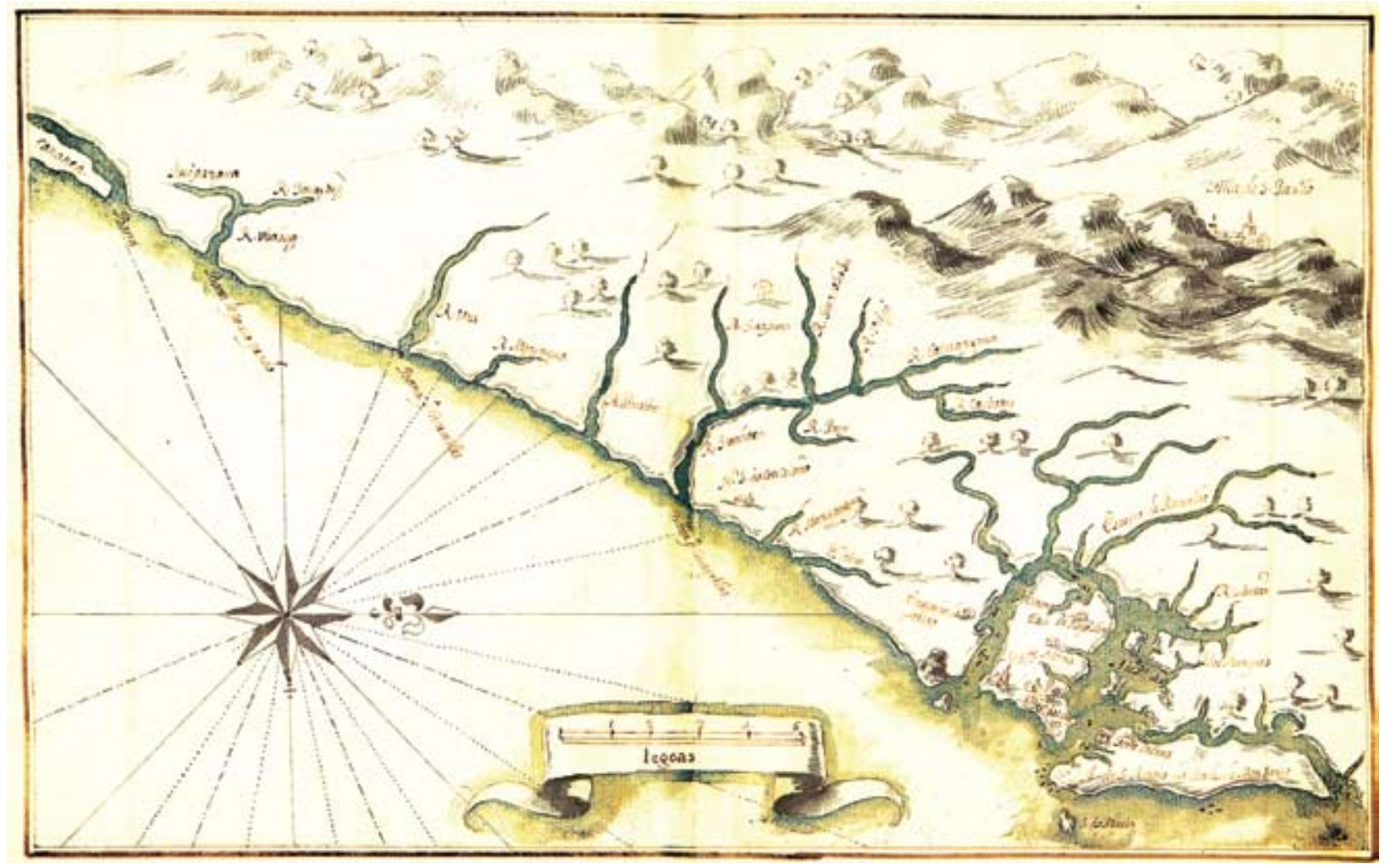

Figura 2 - João Teixeira Albernaz I, Descripção de todo o Maritimo da Terra de S. Crus chamado vulgarmente o Brazil. [c. 1640]. Coleção Brasiliana/Fundação Estudar. Acervo da Pinacoteca do Estado, São Paulo. Fonte: "Descripção..."(2003). 


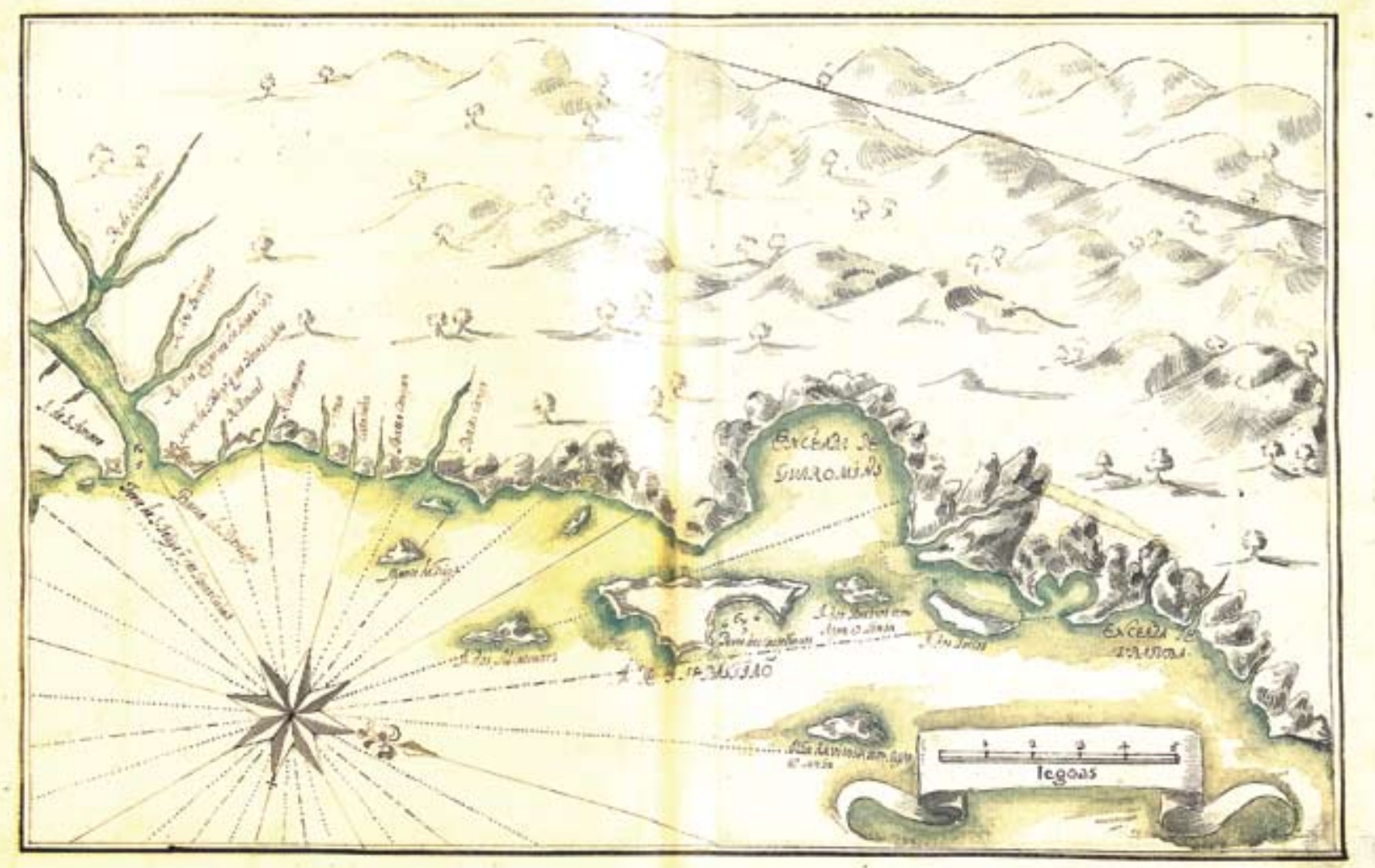

Figura 3 - João Teixeira Albernaz I, Descripção de todo o Maritimo da Terra de S. Crus chamado vulgarmente o Brazil. [c. 1640]. Coleção Brasiliana/Fundação Estudar. Acervo da Pinacoteca do Estado, São Paulo. Fonte: "Descripção..."(2003). 


\begin{tabular}{|c|c|c|c|}
\hline Núcleo-mãe & Século XVI & Século XVII & Século XVIII \\
\hline \multirow[t]{2}{*}{ São Vicente (1532) } & Santos (1545) & São Sebastião (1636) & \\
\hline & Itanhaém (1561) & & \\
\hline \multirow[t]{11}{*}{ São Paulo (1560) } & & $\begin{array}{l}\text { Santana de } \\
\text { Parnaíba (1625) }\end{array}$ & \\
\hline & & Itu (1654) & Porto Feliz (1797) \\
\hline & & & Piracicaba (1774-1776) \\
\hline & & & Mogiguaçu (1769) \\
\hline & & Jundiaí (1665) & Campinas (1797) \\
\hline & & & Mogimirim (1769) \\
\hline & & & Atibaia (1769) \\
\hline & & & Bragança (1797) \\
\hline & & Sorocaba (1661) & Apiaí (1771) \\
\hline & & & Itapeva (1769) \\
\hline & & & Itapetininga (1771) \\
\hline $\begin{array}{l}\text { Mogi das } \\
\text { Cruzes (1611) }\end{array}$ & & Jacareí ( 1653 ) & \\
\hline \multirow[t]{4}{*}{ Taubaté (1645) } & & Guaratinguetá(1651) & Cunha (1785) \\
\hline & & & Lorena (1778) \\
\hline & & & Pindamonhangaba(1705) \\
\hline & & & $\begin{array}{l}\text { São Luís do } \\
\text { Paraitinga (1773) }\end{array}$ \\
\hline
\end{tabular}

A maioria passou por estágios anteriores, como capela e freguesia, antes de ser elevado à categoria de vila. Tal lógica de desmembramento municipal esteve vigente em todo o Brasil, implicando na perda de território (i. e. do termo) por parte da celula mater, certamente envolvendo conflitos de interesses nesses momentos.

Os primórdios da urbanização nas capitanias de São Vicente e Santo Amaro (1534-1711)

Em princípios do século XVI, Portugal é senhor de um vasto império colonial, concentrado sobretudo no Oriente. Com os olhos voltados às lucrativas 
21. Ver A. de Azevedo (1956 p. 11).

22. A vila de São Vicente, como de hábito ora em diante, foi fundada em sítio abundante de víveres, fértil e estratégico - boca de sertão por meio de peabirus -, já previamente ocupado por portugueses (degredados, náufragos, desertores ou aventureiros), espanhóis, índios aliados dos portugueses e mamelucos envolvidos no apresamento de indígenas. Ver: A. Zequini (2004, p. 36) e R. Gianessella (2008).

23. Ver N. G. Reis Filho (2001).

24. Idem, ibidem. rotas comerciais da África e Ásia, fascinado por produtos ali encontrados, exóticos aos olhos do mercado europeu, Portugal mostrava-se desinteressado pelo território descoberto nas Américas em 1500, uma vez que ele parecia oferecer pouco aos famigerados intentos da política mercantilista em vigor.

Nas três primeiras décadas do século XVI, a Coroa portuguesa empenhou-se em mandar ao novo mundo apenas umas poucas expedições de reconhecimento da costa, estabelecendo algumas feitorias que não passaram de meros pontos de escala, sinais de posse, bases de policiamento da costa, entrepostos de coleta de pau-brasil - único produto aí encontrado que interessava ao mercado europeu. Essas feitorias de caráter militar tiveram função econômica insignificante, muitas delas não chegando a enraizar-se no local em que foram fundadas. Segundo Aroldo de Azevedo ${ }^{21}$, não passaram de 12, desaparecendo posteriormente. Restaram Cabo Frio e Igaraçu.

A visitação de estrangeiros à costa, sobretudo franceses em busca de pau-brasil, foi estimulada pelo desinteresse português. Assim, em 1532, D. João III decidiu colonizar a América portuguesa, única forma de manter a posse das terras descobertas. Enviou o fidalgo Martim Afonso de Souza que, em conformidade com as instruções trazidas, subiu ao planalto e percorreu a costa sul até o Prata, distribuiu terras e fundou a vila de São Vicente 22 [1532], que constitui o marco inicial de um novo período.

Decidindo-se pelo sistema (já experimentado em Cabo Verde) de capitanias hereditárias, a partir de 1534 a Coroa dividiu com fidalgos portugueses o ônus ${ }^{23}$ do projeto de colonização. Aos donatários coube a função de fundar vilas, conceder terras, defender a costa, dinamizar e povoar o território da sua capitania, portanto, a de viabilizar a colonização.

A realidade não se concretizou da maneira esperada. As adversidades impediram o desenvolvimento das propostas iniciais. $\bigcirc$ plantio da cana-de-açúcar (produto também experimentado em Cabo Verde e São Tomé, então escolhido com vistas ao mercado externol só se efetivou em algumas capitanias - São Vicente e Pernambuco. $\bigcirc$ fracasso gerou a necessidade de constituição de um governo metropolitano na Colônia, o Governo Geral (1548/1549), que teve como sede a Cidade de Salvador da Bahia de Todos os Santos (1549), criada em território reincorporado pela Coroa. Com o primeiro governador-geral, vieram os jesuítas, que em muito auxiliaram no processo de adaptação às adversidades da colônia. A política urbanizadora, decorrente da política de colonização, até meados do século XVII consistiu apenas na fundação de cidades reais pela Coroa, com função de controle regional, e no incentivo da formação de vilas por iniciativa e às custas dos donatários. A Coroa procurou utilizar ao máximo os recursos dos particulares ${ }^{24}$.

Rigoroso frio dominava o planalto da Capitania de São Vicente, frio esse que, aliado às dificuldades de acesso ao litoral, ali inicialmente inviabilizaram o plantio da cana-de-açúcar, limitando-o a fazendas na costa. Embora desde o início se produzisse algum açúcar e aguardente na Capitania de São Vicente, essas atividades atendiam apenas às necessidades locais, devido às dificuldades 
de transporte, e só adquiriram importância na segunda metade do século XVIII ${ }^{25}$. Nos inventários das capitanias de São Vicente e Santo Amaro é revelada extrema austeridade. Como as cartas do atlas de Albernaz o demonstram, no século XVI e princípios do XVII, a área efetivamente povoada limitava-se à costa, salvo a Vila de São Paulo de Piratininga, uma exceção, situada no planalto por ação dos jesuítas. Embora elevados à categoria de vila, os cinco núcleos quinhentistas São Vicente, Santos, Itanhaém, Iguape e São Paulo - eram bastante diminutos; meros povoados de casas de pau-a-pique ${ }^{26}$, cobertas de sapé, à maneira indígena, um pelourinho, uma igrejinha, geralmente cercados por paliçadas lapenas por ordem do governador-geral D. Francisco de Souza, substituídas por muros de taipa de pilão). Nesses núcleos primitivos, é marcante a presença dos jesuítas, que procuravam auxiliar no tratamento com o gentio.

Para chegar ao planalto, havia apenas o chamado Caminho de Paranapiacaba, antiga trilha dos indígenas. Posteriormente, em 1553, fez-se o Caminho do Padre José, que saía na altura de Cubatão. Nesses primeiros tempos, a rede urbana era frágil, e a simbiose com os indígenas, uma estratégia de sobrevivência. Durante os primeiros séculos, os índios compunham a maior parte da população local, e toda a expansão se fez através de suas velhas trilhas ${ }^{27}$. Essa singular combinação de índios, mestiços e brancos conferiu feição particular aos vicentinos.

Os anos da dominação espanhola, por ocasião da união das coroas ibéricas (1 580-1640), marcaram a consolidação da vitória contra os franceses, sobretudo na costa norte do Brasil e no Rio de Janeiro. Tal avanço era parte de uma deliberada política dos felipes, traçada e executada em obediência a planos concretos. Além de livrar da posse dos franceses grande parte do norte, nordeste e sudeste, a política felipina promoveu a elaboração sistemática de relatórios sobre o território colonial - as Relaciones Geographicas de Indias - e estimulou a interiorização de sertanistas em busca de metais preciosos, articulada à abertura de caminhos, ao povoamento e à conquista do sertão em torno à Vila de São Paulo.

Nas antigas capitanias de São Vicente e Santo Amaro, desde 1624 chamadas de capitanias de Itanhaém e São Vicente, cinco núcleos - três situados no litoral e dois no planalto - foram elevados à categoria de vila: São João Batista de Cananeia, São Sebastião, Exaltação da Santa Cruz do Salvador de Ubatuba, Santana de Mojimirim (atual Mogi das Cruzes) e Santana de Parnaíba.

Os novos núcleos do planalto deveram-se aos estímulos de buscar metais, encabeçados por D. Francisco de Souza - 70 Governador Geral do Brasil - que, em 1599, em função das notícias sobre mineração de ouro e ferro no Jaraguá, transferiu residência de Salvador para São Paulo, aí falecendo em $1611^{28}$

No entanto, havia uma razão específica nesse programa de estímulo à interiorização e povoamento de novas áreas, concomitante à busca de metais. Nesse período, o açúcar passou a dominar, em importância, o mercado mundial, assim permanecendo durante um século. Na segunda metade do século XVI, o
25. Cf. F. V. Luna e H. S Klein (2005, p. 26).

26. Cf. N. G. Reis Filho (2004, p. 28): "a Vila de São Paulo com casario modesto, de taipa de mão ou pilão, térreo e coberto de palha, $\mathrm{e}$ população girando em torno de 2.000 pessoas na fase inicial".

27. Cf. F. Vidal Luna e H. S Klein $(2005$, p. 31; 33). Entre as trilhas abertas na mata, destacam-se os peabirus, sistema de caminhos indígenas que interligava várias localidades da costa brasileira - $\mathrm{CO}^{-}$ mo o porto dos Patos, Cananéia e São Vicente - ao atual Paraguai.

28. Cf. N. G. Reis Filho (2004, p. 31; 34). 
29. Ver S. Sideri (1978); A. A. Bourdon (1973); A. F. Ferreira (1977); C. A. Hanson (1986); e J. B. de. Macedo (1982, p. 11-32)

30. Ver S. B. de Holanda (1994; 1966). império espanhol atingiu seu apogeu terrestre e marítimo, sendo interessante, inclusive para Portugal, a união das coroas em 1580. A mudança da base econômica das especiarias para o açúcar condicionou um aumento do número de engenhos no Brasil no último quartel do século XVI. Em contrapartida, o monopólio português na Rota do Cabo encontrava-se, desde 1595, abatido pelos holandeses e ingleses, que reduziram a menos de $1 / 3$ o comércio dos portugueses no Oriente. Os carregamentos de especiarias diminuíram, portanto, em 1/3. Em função da concorrência inglesa e holandesa, cada vez mais aguda, Portugal simpatizou com a união das duas coroas - as grandes envolvidas nesse comércio progressivamente ameaçado pela concorrência de outras potências ultramarinas. Em 1612, os franceses instalaram-se definitivamente no Maranhão. Em 1624 (após o fim da trégua com as Províncias Unidas dos Países Baixos), a Companhia das Índias Ocidentais, criada em 1621, fez sua primeira investida na Bahia, sendo os holandeses expulsos no ano seguinte. Nova tentativa ocorreu em 1627. Em 1628, Piet Heyn tomou, perto de Cuba, toda uma frota espanhola de carregamento de prata; em 1630, ocorreram os primeiros ataques a Recife e Olinda; em 1634, à Paraíba; em 1635, a Capitania de Pernambuco foi totalmente conquistada. Se não bastasse a tomada da região mais importante de produção de açúcar, os holandeses ainda atacaram, em 1637, São Jorge da Mina e, em 1638, Angola. Isso sem contar o apresamento - de 1623 a 1638 - de 547 navios carregados de açúcar. Resultado: perda do ouro africano e dos tratos do golfo da Guiné; forte diminuição da área açucareira e tabaqueira; toda a agricultura e comércio do açúcar gravemente atingidos; Angola ameaçada e a fonte de escravos comprometida; além de insegurança na navegação através dos oceanos ${ }^{29}$.

Esta conjuntura internacional condicionou a política felipina de estímulo às "entradas" e "bandeiras" dos sertanistas, em busca de ouro e de indígenas escravos (que a África negra agora recusava). A necessidade de conviver no planalto gerou nos vicentinos desembaraço no sertão. A familiaridade com o gentio, o aprendizado dos segredos do sertão e dos mecanismos de sobrevivência, condicionaram um tipo humano, meio português e meio índio, o mameluco, imortalizado na obra de Sérgio Buarque de Holanda ${ }^{30}$. Era estratégico acioná-los neste momento, para dilatar a presença metropolitana em solos do ultramar.

Esse estímulo a interiorizarem-se no sertão, em busca de metais preciosos e escravos, gerou intermináveis conflitos com a Companhia de Jesus, que dominava, na época, vastos territórios subtraídos da jurisdição metropolitana, administrando-os economicamente de maneira autônoma, conforme seus próprios interesses. Tendo como fundamento assegurar a "liberdade" do índio, os jesuítas subtraíam abundante mão-de-obra, contrariando brutalmente os interesses metropolitanos de então. Na década de 1620, agudizou-se o antagonismo. Em 1624, os paulistas destruíram algumas aldeias e reduções jesuíticas. De 1630 a 1635, fizeram novas incursões ao Paraguai. Sedes de colégios dos padres jesuítas - no Rio de Janeiro, Santos e São Paulo - vivenciaram violentos motins, que culminaram com a expulsão dos padres de São Paulo e Santos. Regressaram 
a São Paulo em 1640 e 1653; no entanto, em 1658, os paulistas voltaram a atacar as missões do Paraguai. A sociedade civil paulista, ansiosa por viabilizar a colonização mesmo às custas da escravização dos indígenas, pôs-se em luta contra o Estado teocrático aqui estabelecido. Como deixariam de entrar em conflito, em tempos de crise, se já no século XVI tantas vezes os interesses e orientações dos missionários chocavam-se com aqueles dos leigos, colonos e mercadores. A crise de todo o império hispano-português agravou tensões e desencadeou enfrentamentos.

Em 1640, os portugueses clamavam pela "Restauração do Trono". As grandes fortunas de Portugal viram suas expectativas frustadas quanto aos benefícios da união das coroas ibéricas. Castela não logrou policiar os mares, e não se concretizou o desejo de associação na exploração das "maravilhosas" minas de prata da colônia espanhola. Os portugueses - impossibilitados de fornecer mão-de-obra africana em função da insegurança marítima e da presença dos holandeses em seus principais entrepostos - colaboraram no declínio da produção da prata, dada a escassez de mão-de-obra. Consequentemente, em 1640, Castela impediu a presença de estrangeiros em suas atividades coloniais. Tal atitude marcava o fim de qualquer esperança de parceria rentável. Afinal, o domínio espanhol foi uma ilusão e, sobretudo, um mau negócio. $\bigcirc$ fim dos interesses marcou o fim da união ${ }^{31}$.

No entanto, no que tange às capitanias dos herdeiros de Martim Afonso e Pero Lopes de Souza representou progresso. A mineração de ouro ${ }^{32}$ estimulou a caça aos silvícolas, para o abastecimento de mão-de-obra nas minas, gerando um período extremamente dinâmico na região sudeste da colônia, até então à margem da economia de exportação. $\bigcirc$ resultado foi o surgimento de uma série de novos arraiais, alguns deles merecendo foros de vila. No litoral, as vilas de Cananeia, Iguape e Paranaguá, amparadas pelos jesuítas le isoladas do que se podia chamar de eixo principal de trânsito da capitania: São Paulo-Santos-São Vicente), começaram a polarizar importante território voltado à mineração de ouro. $\bigcirc$ litígio entre os herdeiros dos antigos donatários das duas capitanias gerou a perda de Santos, São Vicente e São Paulo para os herdeiros de Pero Lopes. A antiga Capitania de São Vicente, passou a ser chamada de Capitania de Itanhaém, em função da transferência da sede de seu governo para a Vila de Nossa Senhora da Conceição de Itanhaém. As descobertas e explorações dessas minas de ouro de lavagem na região do vale do Ribeira e baía de Paranaguá dinamizaram a economia local. A exploração do ouro foi feita com mão-de-obra indígena, amplamente escravizada para tanto, convertendo-se em excelente negócio, para os paulistas, aprisioná-los para abastecer as zonas de mineração. John Monteiro ${ }^{33}$ admite a existência do tráfico de índios inclusive para outras capitanias, mas refuta a sua importância. $\bigcirc$ grosso da mão-de-obra escravizada direcionava-se às minas locais ${ }^{34}$. Mesmo assim, quanto à dimensão, por exemplo, a vila de lguape era tão humilde e tão pequena, que, em 1679, o capitão-mor Luiz Lopes de Carvalho, ouvidor de ltanhaém lem edital, em nome do conde donatário), determinou que, "em vista das poucas
31. Ver S. Sideri (1978); A. A. Bourdon (1973); A. F. Ferreira (1977); C. A. Hanson (1986); e J. B. de. Macedo (1982, p. 11-32).

32. Sobre a mineração nas Capitanias de São Vicente e Santo Amaro nos séculos XVI e XVII, Nestor Goulart desenvolveu estudo recente, ainda inédito, que revela a exploração de ouro no morro do Jaraguá, nos arredores de São Paulo (Guarulhos, Suzano, Osasco, Itapecerica da Serra e Franco da Rocha), em Santana de Parnaíba, Araçariguama, no vale dos rios Sorocaba e Paranapanema, em Apiaí, no planalto curitibano, no vale do Ribeira e na baía de Paranaguá.

33. Cf. J. Monteiro (1994, p. 76-81).

34. Em relatório elaborado para o IPHAN (2008-2009), Nestor Goulart Reis Filho localizou as áreas de mineração paulistas, analisando a concomitante questão da escravização dos índígenas e demonstrando que o grosso sempre se destinou ao mercado local. Texto inédito, gentilmente cedido pelo autor. 
35. Ver Revista do IHGSP (1915).

36. Ver F. M. Santos (1937). moradas que haviam na vila, fosse cada um obrigado, dentro de um ano, a fazer a sua casa, tendo cem mil réis de bens para cima, sob pena de dez cruzados de multa" ${ }^{\prime \prime}$.

Em função da ânsia de escravização dos indígenas, ao longo de todo o século XVII a luta contra os jesuítas tornou-se constante, deixando estes de servir para o auxílio dos indígenas e em seu controle. Agora, o novo período de caça ao silvícola os convertera em grandes inimigos das lucrativas empreitadas. Mas, sem dúvida, os inacianos tiveram papel decisivo na ocupação, desenvolvimento e definição do território paulista. No planalto, deram início à povoação de Piratininga; salvaguardaram a existência de povoações ao longo da costa, como Cananeia, Itanhaém, Paranaguá, São Vicente e Santos; foram importantes responsáveis pela sustentação dessa frágil rede urbana dos primeiros tempos da Capitania. Navegaram rios, avizinharam-se do Paraguai, abriram rotas e possibilidades de expansão. Em 1553, o padre Manoel da Nóbrega navegou o rio Anhembi (Tietê), chegando próximo ao Paraguai. O trajeto pelos rios Tietê, Paraná, até o Prata (Assunção) e vice-versa era habitual. Durante o governo de Mem de Sá, em função das contínuas lutas contra os indígenas confederados, diversas vezes se passava por essas regiões. Os paulistas desciam, os espanhóis subiam o curso do rio Tietê e o comércio incipiente já se dilatava, tendo por base as trocas de produtos nativos ou cultivados. $\bigcirc$ apresamento do silvícola foi, sem dúvida, o maior incentivo às viagens sinuosas dos intrépidos sertanistas, mas não o único aspecto determinante da expansão e interiorização. Muitos procuraram, desde o início, fazer roças mais afastadas, onde houvesse mais facilidade de encontrar terras melhores e ainda virgens, mantendo o velho costume indígena da agricultura itinerante. A interiorização foi lenta, mais progressiva. Os primeiros colonizadores, sobretudo os vindos com Martim Afonso, obtiveram sesmarias e, nelas, aos poucos criaram agrupamentos, e os agrupamentos geraram a necessidade de auxílio espiritual (necessário para aqueles homens estabelecidos em universo tão inóspito). Assim foram fundadas as primeiras povoações no planalto além da vila de São Paulo de Piratininga.

Primeiro, Santana de Mojimirim (atual Mogi das Cruzes), nas cabeceiras do rio Tietê, fruto de povoamente estimulado por D. Francisco de Souza por ocasião da abertura de caminho ligando Boigy (antigo nome do local) a São Paulo, em 1601, que deu origem à sesmaria solicitada pelo fidalgo português Brás Cubas. Exercendo o cargo de capitão-mor, lugar-tenente de Martim Afonso (o donatário da Capitania de São Vicente), Brás Cubas pôde dar origem não só a Santos ${ }^{36}$ (1545), mas também a esse agrupamento no planalto, elevado, em 161 1, à categoria de vila. Os mogianos organizaram "entradas" e "bandeiras" ou, à procura de ouro e à cata de índios, acompanharam-nas.

Também fruto da era martim-afonsiana, após se estabelecer em São Vicente e São Paulo (onde exerceu cargos administrativos), Manuel Fernandes Ramos, natural de Moura, recebeu sesmaria de oito léguas ao longo do rio Tietê, nas proximidades da vila de São Paulo de Piratininga, onde seus herdeiros iniciaram fazenda em 1580. Ali, seus filhos e esposa distribuíram terras aos 
parentes e amigos. Assim, foram aparecendo moradores em torno da capela, então construída às margens do rio, no trecho em que se tornava encachoeirado. A cultura de produtos de subsistência e de cana-de-açúcar lque teria vindo de São Vicente) supria as necessidades básicas e a descoberta de ouro nas imediações estimulou a permanência desse pequeno núcleo humano. Produtos da lavoura eram permutados com outros; casas iam surgindo aqui e acolá, cobertas de folhas. Nascia assim Santana de Parnaíba ${ }^{37}$. $\bigcirc$ fundador, padroeiro e instituidor da capela André Fernandes (filho de Manuel Fernandes), por ordem régia, fez inúmeras entradas oficiais no sertão - quer na luta contra os jesuítas, participando da destruição das Missões do Guairá ( 1 629-1 630), quer à procura de índios e metais preciosos. Essa sesmaria compreendia toda a região de Parnaíba, Itu, Sorocaba e São Roque. Cada um dos filhos de Manuel Fernandes recebeu em herança uma fração dessas terras, estabelecendo ali ao redor novas povoações que, ao longo do século, obtiveram da Coroa Portuguesa os foros de vila: em 1657, Nossa Senhora da Candelária do Outu; e, em 1661, Nossa Senhora da Ponte de Sorocaba ${ }^{38}$.

A ocupação do sertão seguiu novos rumos. Deixando São Paulo, via Carapicuíba, penetrava-se em terras de Parnaíba, onde, desde 1580, Suzana Dias e André Fernandes haviam aberto a mata serrada. Noutra direção, contornando o morro do Jaraguá, no sertão do rio Jundiaí, foi fundado um povoado, fruto da ação dos parnaibanos. Elevado a vila em 165539, as origens de Jundiaí são bastante obscuras, mas sabe-se que até então a civilização paulista terminava no morro do Jaraguá, onde, em fins do século XVI, Affonso Sardinha descobriu e extraiu ouro. Foi Jundiaí, portanto, a primeira povoação além-Jaraguá, dando ensejo a uma série de outras nessa direção.

Outra frente de urbanização, fruto da ação dos mogianos, ocorreu às margens do rio Paraíba, onde, no século XVII, fundaram Taubaté, Jacareí e Guaratinguetá. Sabe-se que, desde o período quinhentista, o Vale do rio Paraíba foi não só um eixo de passagem mas um objetivo. $\bigcirc$ apresamento de índios teve enorme importância na incorporação desse sertão à Capitania de Santo Amaro. Foram concedidas sesmarias nas margens do Paraíba, povoando-se o vale com o auxílio do rio e de um caminho a ele paralelo. Seguindo trilhas indígenas anteriores, a expansão deu-se em todas as direções. Outras trilhas indígenas pré-existentes foram aproveitadas e melhoradas pelos intrépidos mogianos e taubateanos. Em algumas das sesmarias concedidas, esses caminhos primitivos condicionaram o surgimento de povoações. $\bigcirc$ Caminho dos Guainás - que subia de Parati, passando pela freguesia do Facão (Cunha), atingindo Guaratinguetá - viabilizou o surgimento desses dois núcleos no planalto e dinamizou o porto de Parati (elevado a vila em 1660), pertencente à Capitania do Rio de Janeiro. Outras trilhas interligadas a rotas fluviais ligavam o planalto ao litoral, de Taubaté a Ubatuba e de Jacareí a São Sebastião.

Ao contrário do que pensaram os portugueses, a "Restauração do Trono" não deu fim à crise em que estavam mergulhados. Portugal, embora tenha retomado (das mãos da Companhia das Índias Ocidentais) possessões na África
37. Ver P. F. da S. Camargo (1971).

38. Ver A. de. Almeida (1969).

39. Ver M. Mazzuia (1976) 
40. Ver S. Sideri (1978); A. A. Bourdon (1973); A. F. Ferreira (1977); C. A. Hanson (1986); e J. B. de. Macedo (1982, p. 11-32)

41. Idem, ibidem.

42. Ver G. Martins (1973).

43. Cf. F. Vidal Luna e H. S Klein (2005, p. 25-53); e C. D. Fonseca (2003) e no Brasil, deparou-se com a triste realidade da perda progressiva de monopólios importantes. A Rota do Cabo deixara de ser o eixo do império português, e a economia do açúcar estava em franco declínio. $\bigcirc$ Brasil mantinha-se como o maior produtor, mas, dada a concorrência dos holandeses nas Antilhas, não mais monopolizava o mercado. Feito um balanço, poucas iniciativas foram tomadas pela Coroa para socorrer a economia do açúcar. Ao invés disso, concentrou seus esforços em extrair tudo quanto podia de uma indústria estagnada ${ }^{40}$.

Durante o reinado de D. Pedro II (1668-1706), foram estabelecidos cinco programas de estímulo ao desenvolvimento da colônia. Na ocasião, com vistas a aumentar os rendimentos da Coroa, foram desencadeadas ações diretas e enérgicas no sentido de buscar outras atividades que pudessem dinamizar a economia colonial: 1. novo programa de incentivo à caça ao ouro; 2. criação da Colônia do Sacramento, visando a atrair o comércio da prata peruana; 3. encorajamento ao cultivo de sementeiras transportadas do Extremo Oriente para as capitanias do norte do Brasil, tentando desenvolver o cultivo de especiarias na América Portuguesa; 4. instituição da Junta do Tabaco, no esforço de explorar um melhor produto que pudesse ajudar a preencher a lacuna deixada pela economia do açúcar, em franco declínio; 5. tentativa de recuperar o contrato do monopólio de fornecimento de escravos africanos. Desses programas, dois atingiram diretamente as capitanias paulistas: a nova fase de estímulo à caça ao ouro e a fundação, no estuário do rio da Prata, da pequena povoação da Colônia do Sacramento $(1680)^{41}$.

Há décadas vinha se processando a procura da riqueza mineral no Brasil, ocorrendo descobertas de metais e pedras preciosas nas imediações de São Paulo, de Santana de Parnaíba, do vale do Ribeira e da baía de Paranaguá, mantendo vivo o sonho da existência de mais riquezas nas longínquas terras do interior. A partir de 1668, a nova política metropolitana de estímulo dinamizou a procura. Afonso Furtado de Castro do Rio de Mendonça lgovernador-geral empossado) e outros oficiais foram encarregados de encorajar a descoberta de novas minas. A administração de Mendonça marcou uma época de grande atividade na busca de ouro, prata e esmeraldas. Os colonos foram incessantemente estimulados à descoberta de riqueza mineral. Ofertas de títulos de nobreza e outras formas de recompensa atuaram como incentivo para os sertanistas que, finalmente, puseram a descoberto os grandes tesouros das minas de Cataguazes em 1693/1695.

Taubaté ${ }^{42}$, elevada à condição de vila desde 1645, foi um dos polos de irradiação, bem como São Paulo e São Vicente e, posteriormente, Itu e Sorocaba. Coube aos taubateanos as primeiras descobertas das minas de Cataguases ${ }^{43}$. Expedições atravessaram a serra da Mantiqueira pelas gargantas do Sapucaí ou do Embaú. Do vale do Paraíba partiram centenas de "entradas" e "bandeiras", dirigindo-se às minas. Os núcleos ali estabelecidos, já elevados à condição de vila no período que se seguiu à "Restauração", desenvolveram-se e se integraram ao novo frenesi de busca de ouro e metais preciosos. De Guaratinguetá, partiram expedições às minas, bem como da nascente povoação de Pindamonhangaba. $\bigcirc$ 
chamado Caminho Velho para as minas de Cataguases, apresentava o seguinte 44. Ver G. Martins (1973). roteiro: de Taubaté ia-se até a freguesia de Piedade (atual Lorena) e dali cruzava-se a Mantiqueira em direção ao sertão das minas. Não havia um caminho direto entre as minas e o Rio de Janeiro, o que obrigava o trajeto inverso: Minas / Piedade (Lorena) / Taubaté / Facão (Cunha) / Parati / Rio de Janeiro. O detalhe da Carta 9a. dos padres matemáticos revela a trilha percorrida entre Piedade e o porto de Guarauna (Parati), pontuada por inúmeras capelas (Figura 4).

A Casa dos Quintos (1695) foi destinada a Taubaté44, ponto obrigatório de passagem, e, a seguir, a Casa de Fundição (1697). O objetivo era combater a sonegação, legalizando o metal e cobrando a conhecida quinta

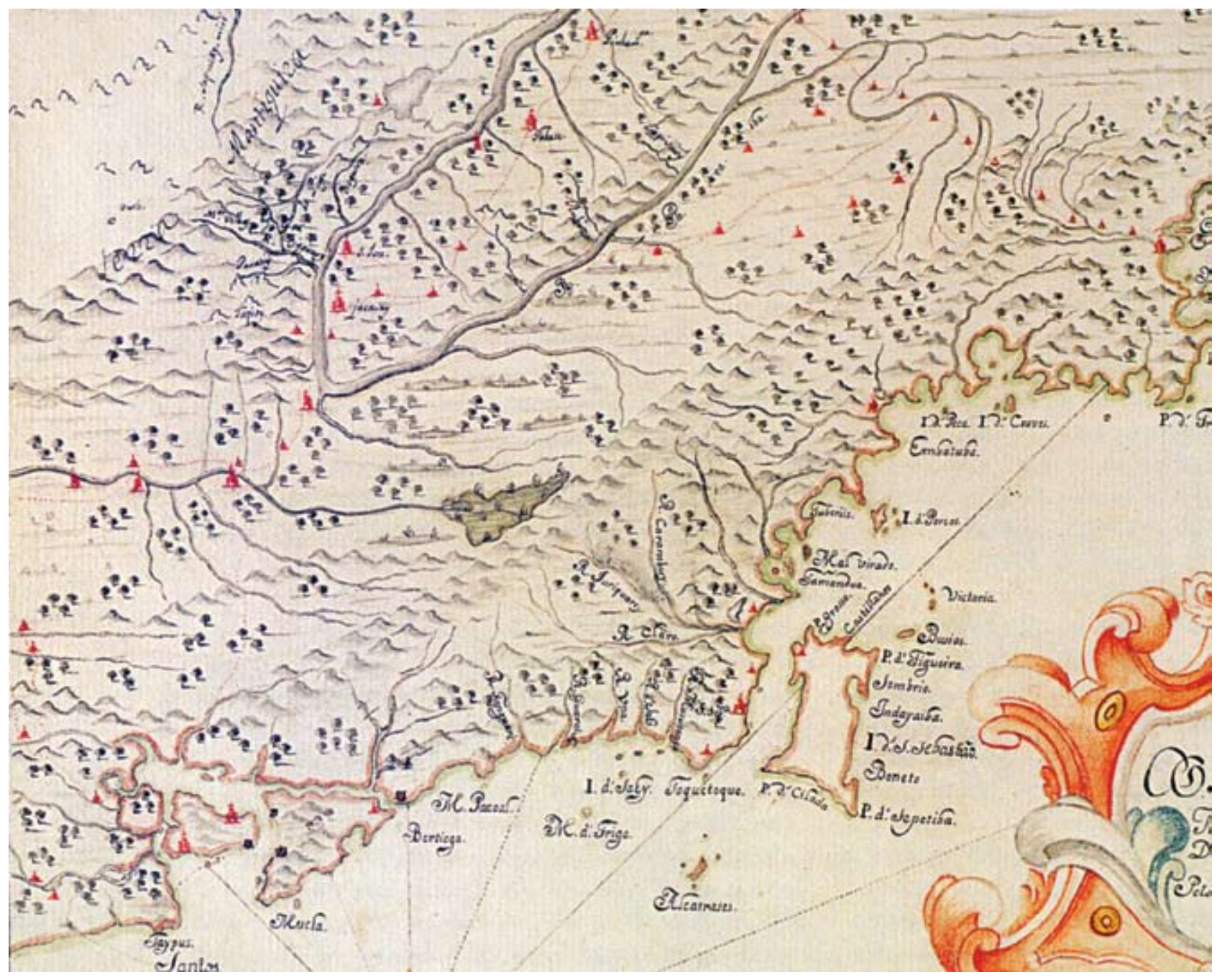

Figura 4 - $\bigcirc$ detalhe da carta dos padres matemáticos revela a rede urbana, viária e fluvial do planalto paulista (especialmente do vale do Paraíbal e suas articulações com o litoral, bem como destaca a incomunicabilidade das bacias do rio Tietê e do Paraíba do Sul. Diogo Soares e Domingos Capassi. Da costa do Brazil desde a Barra de Santos até à da Marambaya. Carta IX. [c. 1737]. 18,8cm x 31,7cm. Arquivo Histórico Ultramarino, Lisboa. 
45. Gêneros de primeira necessidade provinham do Vale do Paraíba; aguardente, escravos e artigos de luxo, do Rio de Janeiro, via Parati; gado bovino, da Bahia; gado bovino, equino e muar, do sul, via Sorocaba. Observa-se a formação de um intenso mercado interno de trocas intercapitanias na Colônia. Ver M. Zemella (1951); M. Ellis (1961); e F. Vidal Luna e H. S. Klein (2005, p. 25-53). parte destinada à Coroa. Durante os fins do século XVII, Taubaté funcionou como o ponto oficial de manipulação e encaminhamento do metal ao reino. Tudo quanto se dirigisse às Minas passava por Taubaté, inclusive os próprios baianos que, nos primórdios da mineração, tendo passe livre no território aurífero, voltavam para sua terra entrando pelo rio São Francisco através de Taubaté. $O$ mesmo acontecia com os gêneros alimentícios ${ }^{45}$, roupas, animais e escravos, destinados ao longínquo sertão das Gerais. Foram os taubateanos os verdadeiros abastecedores das minas, e a rota do vale do Paraíba a mais importante em fins do século XVII e nas três primeiras décadas do século XVIII. Embora severamente vigiado, sonegava-se o ouro; e tornou-se ineficiente o procedimento utilizado na Casa de Fundição taubateana, que cunhava as barretas a martelo, viabilizando a fabricação de cunhos falsos. Portugal determinou, em 1702, que Taubaté fosse aparelhada com uma máquina de cunhar. Mas as dificuldades do trajeto (via Parati), dado as péssimas condições do Caminho do Facão, impossibilitaram o transporte do engenho cunhador para Taubaté. A permanência da máquina em Parati levou o capitão-mor a transferir a Casa dos Quintos e a de Fundição para o litoral. Na primeira década do século XVIII, os conflitos nos territórios auríferos - entre paulistas, reinóis e baianos - são indícios do fim do monopólio dos primeiros na região descoberta. A pequena sociedade urbana do vale do Paraíba, que durante décadas fervilhara com o comércio, iniciou seu período de declínio.

\section{A Capitania de São Paulo e Minas de Ouro (171 1-1765)}

Em 1709, em função das descobertas auríferas, a Coroa reincorporou, por compra, os territórios já bastante dilatados das antigas capitanias de São Vicente e Santo Amaro, para controlar efetivamente a nova região que, cada vez mais, crescia em importância aos olhos metropolitanos. Para sede da Capitania de São Paulo foi escolhida a vila de São Paulo dos Campos de Piratininga, elevada à condição de cidade em 1711. A criação dessa Capitania de São Paulo e Minas de Ouro marcou não só o início de um período de absoluta centralização administrativa de Portugal em relação ao Brasil mas, principalmente, o menosprezo por aqueles que muito tinham contribuído para a dilatação da Conquista: os donatários e demais colonos.

No final do século XVII, encontramos a então Capitania de São Paulo e Minas de Ouro com limites completamente diversos das primitivas Capitanias de São Vicente e Santo Amaro, que the deram origem. A sua própria denominação refletia a mudança. Com uma rede urbana bastante ampliada e um território em grande parte explorado, interiorizado, podemos dizer que, de periferia, a capitania passou a grande polo transformador dos destinos econômicos da colônia. Encerrou esse segundo século com um conjunto de 14 novas vilas que, sem dúvida, constituem uma representação espacial da mudança dos interesses 
metropolitanos em relação à região. Cada novo caminho oficial, cada nova vila e cada nova alteração de traçado urbano consistia na oficialização dos passos dos diversos atores envolvidos no processo de colonização. A busca de novas fontes de riqueza condicionou essa interiorização, e cada passo foi oficializado ao sabor dos interesses metropolitanos, merecendo o estatuto de vila. As novas vilas, portanto, não nasceram aleatoriamente (Figura 5).

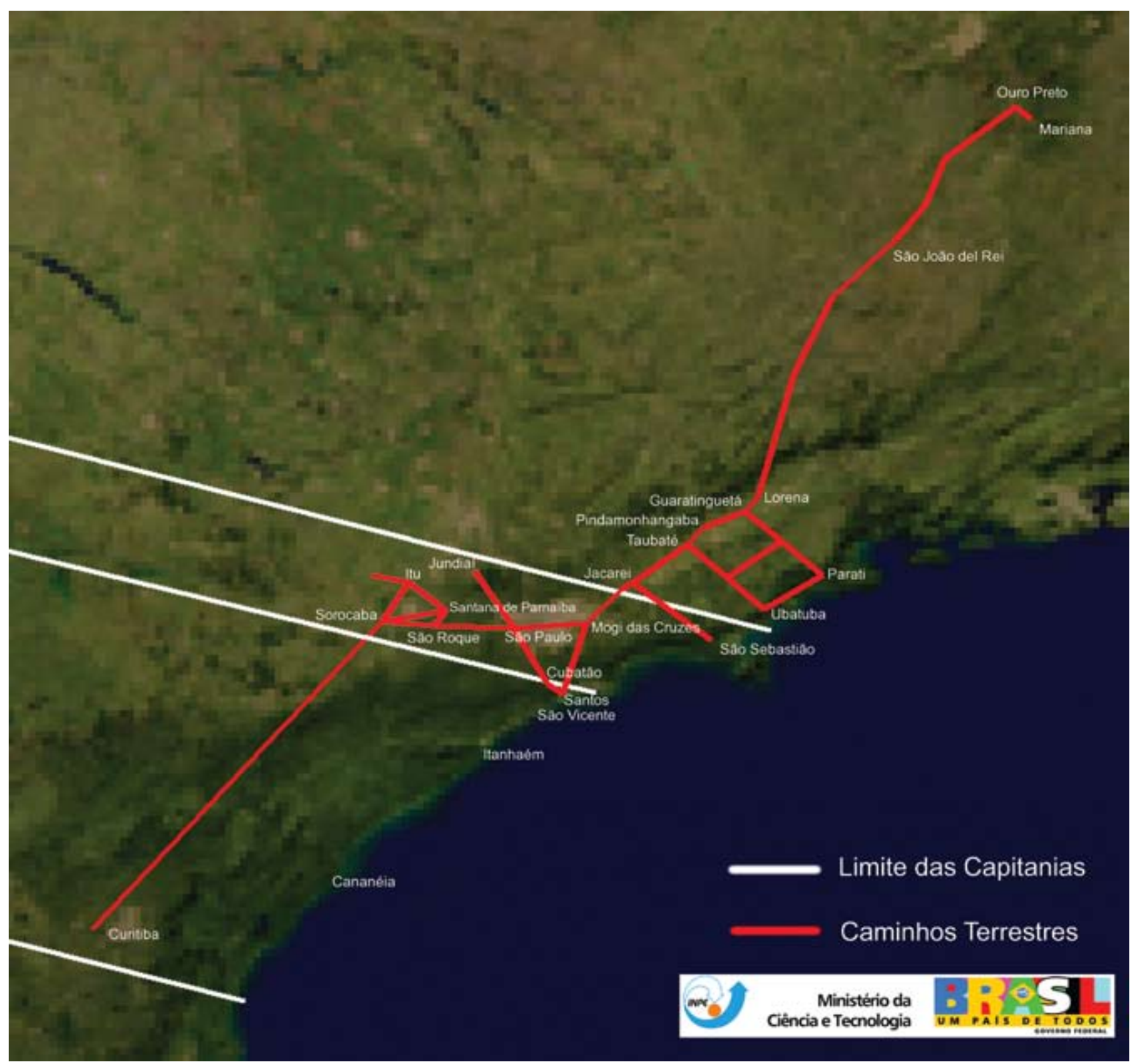

Figura 5 - Reconstituição, baseada em mapas por satélite, dos limites das Capitanias de São Vicente e de Santo Amaro, com a rede urbana, viária e fluvial formada entre 1534 e 1711 . Instituto de Pesquisas Espaciais (INPE), São José dos Campos. 
46. Ver P. T. de A. P. Leme (2004, p. 142).

47. O Caminho Novo, concluído em 1725, ligava o Rio de Janeiro direto com as Minas Gerais, envolvendo o seguinte percurso: Rio de Janeiro-Petrópolis-ItaipavaSecretário-Paraíba do Sul-Paraibuna-Simão Pereira-Matias Barbosa-Caetés-Juiz de ForaEwbank da Câmara-Santos Dumont-Antonio Carlos-Barbacena-Ressaquinha-Carandaí-Cristiano Otoni-Conse1heiro Lafaiete-Ouro Branco-Mariana-Catas AltasSanta Bárbara-Barão dos Cocais-Cocais-Bom Jesus do Amparo-Ipoema-Senhora do Carmo-Itambé do Mato Dentro-Morro do Pilar-Conceição do Mato Dentro-Itapanhoacanga-Serro Frio-São Gonçalo do Rio das Pedras-Diamantina. Cf. A. G. COSTA (2005). O Caminho Velho, vigente desde 1702, seguia o seguinte percurso: São Paulo-Freguesia de Nossa Senhora da Penha-Mogi das Cruzes-Jacareí-Taubaté-Pindamonhangaba-Guaratinguetá-Freguesia de Piedade (Lorena) ou Cruzeiro-São Sebastião do Rio Verde-Baependi-Fazenda Traituba-Carrancas-Caquende-São João del Rey-Lagoa Dourada-São Brás do SuaçiíEngenheiro Corrêa-Ouro Preto-Mariana-Catas AltasBom Jesus do Amparo-Itambé do Mato Dentro-Morro do Pilar-Córregos-Serro Frio-São João dos Rios das PedrasDiamantina. Cf. A. J. Antonil (1966).

O Caminho Velho ligava o Rio de Janeiro a Minas Gerais. Conectando-se em Lorena, seguia a seguinte rota: Rio de Janeiro-Parati-Serra da Bocaina-Cunha-Guaratinguetá-Lorena-Minas.

48. Ver I. Blaj (2000).
Após a Guerra dos Emboadas, os paulistas foram progressivamente expulsos das minas de Cataguases e, por isso, deslocaram-se para mais longe, descobrindo minas em Mato Grosso (c. 1719) e em Goiás (c. 1725).

Na lógica da colonização, a mudança do foco de interesse e a ênfase do controle metropolitano em determinada região condicionava a redefinição do papel das demais regiões. À medida que os segredos revelados nos novos sertões foram merecendo controle por parte da Coroa, houve progressiva decadência em certas áreas.

No fim do século XVII, Santos estava em situação de pronunciada penúria, com todos os gêneros custando uma exorbitância, e o nível de vida extremamente difícil para os desfavorecidos de fortuna. A isso, somou-se a grande epidemia de "bexigas" (varíola), calamidade que assolou a vila de 1665 em diante. Essa pestilência matou 1/3 da população e gerou medidas proibitivas de comunicação, a ponto de ser fechado o Caminho do Mar, interrompendo oficialmente a ligação de Santos a São Paulo: "por aver três meses que estava o caminho do mar fechado he com guardas por ordem desta Camara, a requerimento do povo, por causa de averen bexigas na Vila de Santos"46.

Ao contrário de Santos - nessa época mergulhada em epidemias cíclicas -, São Paulo progredia a olhos vistos. Foi do planalto que partiram as "expedições" de interiorização; foi no interior que se multiplicaram os povoados e concentraram-se todas as atividades de abastecimento dos territórios auríferos, fatos esses coroados, em 1683, com a transferência, para São Paulo, da sede da capitania, em confirmação ao foral de 1681, golpe mortal para os santistas (dada a pobreza da vizinha São Vicente, desempenhara Santos, efetivamente e, durante muitos anos, as funções de capital da Capitania de S. Vicente). Todos os produtos importados vindos do Rio de Janeiro passavam pelo porto de Parati, e não, pelo porto de Santos. Já os muares, bois e cavalos provenientes do sul e os gêneros de primeira necessidade obrigatoriamente passavam pelo vale do Paraíba, dinamizando a rede urbana no planalto e no litoral norte. (Figuras 6)

No entanto, após 1725, com a abertura do Caminho $\mathrm{Novo}^{47}$, ligando as Minas Gerais diretamente ao Rio de Janeiro, entraram em franco declínio e estagnação as vilas do vale do Paraíba. Perdeu-se muito com o deslocamento, para outras paragens, de um trajeto obrigatório intensamente percorrido por quase meio século - sobretudo se pensarmos que, ao longo do Vale do Paraíba, havia importante rede organizada de comércio. $O$ deslocamento da rota levou igualmente à estagnação dos portos situados no litoral norte da Capitania de São Paulo. Desde 1720, Parati deixou de sediar a Casa de Fundição. Aos poucos, toda a população deslocou-se em direção às novas riquezas, permanecendo o litoral praticamente abandonado e isolado do comércio com as minas do ouro. A partir de então, todo o escoamento do metal se fez diretamente via Rio de Janeiro.

Mesmo assim a Capitania de São Paulo se manteve viva, funcionando como entroncamento ${ }^{48}$ de trocas de longa distância com o sul e o centro-oeste. 


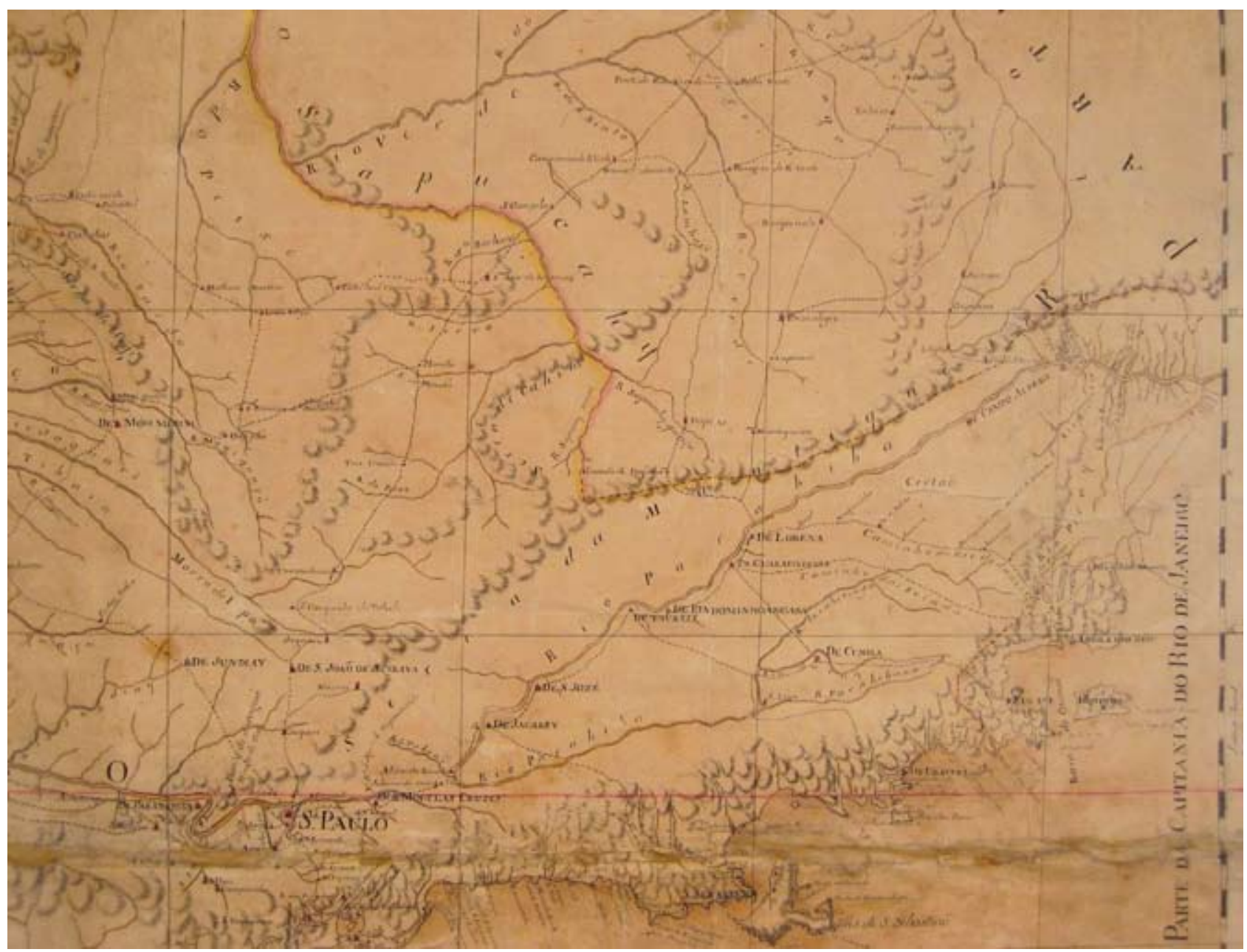

Figura 6 - Rede urbana, viária e fluvial do Vale do Paraíba. Detalhe de: Antonio Rodrigues Montezinhos [engenheiro militar]. Mapa Corographico da Capitania de S. Paulo. 1791-1792. Mapoteca do Itamaraty, Rio de Janeiro.

Não podemos esquecer da enorme expansão, conquistando os sertões - em direção ao sul, ao Mato Grosso, e a Goiás -, obra dos paulistas.

A presença dos portugueses no rio da Prata data de 1680, ao ser fundada a Colônia do Sacramento, com intuito de reforçar a autoridade portuguesa na região e atrair o comércio da prata peruana. Embora o maior estímulo para tal fundação tenha sido abrir caminho para o escoamento da prata da América espanhola via América portuguesa, a realidade e o desenrolar dos fatos demonstraram que o grande lucro e a maior recompensa deste empreendimento foi a pecuária que ali se desenvolveu, sob influência dos castelhanos e jesuítas. Além disso, inúmeras incursões dirigiram-se aos sertões, partindo de Paranaguá, culminando por revelar a existência de metais preciosos nos campos de Curitiba. Na região, desenvolveu-se um povoado, elevado à condição de vila em 1693. Sabe-se que o Caminho de Curitiba, em direção a São Paulo, datava de antes 
49. Em 1728, o governador da Capitania de São Paulo, Caldeira Pimentel, determinou ao militar Francisco de Souza Faria o estabelecimento de uma picada a partir do Viamão, subindo a Serra Geral e chegando aos campos da chamada Vacaria dos Pinhais. Dali, até Curitiba, incorporava-se ao trecho já existente de Curitiba a Sorocaba. Em 1732, esse caminho foi retificado, desviando-se um pouco mais para oeste, denominado de "Caminho do Sul”, com quase 1.500 quilômetros. Cf. V. A. da Silva (2004, p. 84).

50. Cf. R. M. Delson (1997, p. 29).

51. Ver R. Delson (1987).

52. No local do antigo Arraial de Santana, fundado em 1726-1727. da criação da vila, sendo ele progressivamente ladeado por sesmarias. A partir dos primeiros anos do século XVIII, como simples extensão de velhas trilhas indígenas, esta rota se converteu na via de acesso aos campos do sul e trajeto de passagem das tropas de bois, muares e cavalos destinadas a Minas Gerais, Goiás e Mato Grosso, merecendo o nome de Caminho do Viamão, por articular as vilas de Viamão e Sorocaba ${ }^{49}$.

As descobertas auríferas ocorridas nos mais diversos sentidos geraram a necessidade de centralização e controle progressivos. Não por acaso, a Coroa adquiriu, como já dito, as terras das mãos dos antigos donatários e, em 1709, fundou a Capitania de São Paulo e Minas de Ouro, com sede estabelecida na Vila de São Paulo, elevada em 1711 à categoria de Cidade, fato que evidencia concretamente a mudança de atitude e o interesse que a região despertava na Coroa. As atenções se concentravam ali; era preciso transferir toda a administração metropolitana para a região. A nova capital passara a ser ponto-chave de um território superior a três e meio milhões de quilômetros quadrados, quase metade do Brasil. Em 171 1, a Coroa também iniciou franca políitca de urbanização na região das minas de Cataguazes, aspirando a assegurar o controle da área mais valiosa da América portuguesa, agrupando indivíduos em povoados consolidados, reduzindo assim as possibilidades de contrabando. Sob o discurso ideológico de que a ereção de vilas era o melhor meio de "civilizar" e "desenvolver os rudes povoados", o programa do governo, num curto período de sete anos, condicionou a criação de oito novas vilas no território das Minas Gerais: Sabará, N. S. do Carmo (Mariana) e Vila Rica, em 171 1; São João del Rey, em 1712; Vila do Príncipe (Serro Frio) e Vila Nova da Rainha do Caeté, em 1714; Vila Nova do Infante (Pitangui), em 1715; e São José del Rey (Tiradentes), em 171850. Em resposta a quatro estímulos - distribuição de terras; descoberta do ouro; necessidade de lei e ordem no sertão; e ameaça dos futuros interesses espanhóis -, a Coroa cobriu o sertão com essa rede de vilas, fazendo de algumas delas cabeças de Comarca. Os arraiais mineradores que tiveram origem espontânea no decorrer da primeira década foram assim, progressivamente, elevados ao estatuto de vila, alojando os oficiais administrativos provenientes do reino.

Ao longo das quatro primeiras décadas do século XVIII, esse imenso território, cuja administração e jurisdição cabia a São Paulo, foi duplamente ampliado com a descoberta de novas jazidas de ouro nas regiões de Mato Grosso (c. 1719) e Goiás (c. 1725), onde modestos arraiais de mineração foram logo igualmente elevados à condição de vila: Vila do Senhor Bom Jesus de Cuiabá $^{51}$ (1726) e, dez anos mais tarde, Vila Boa de Goiás $s^{52}$ (1736). Da cidade de São Paulo, uma rede fluvial e viária espraiava-se em direção ao oeste e ao sul, ultrapassando - e muito - a Linha de Tordesilhas.

A partir de 1720, a dificuldade para controlar tão vasto território levou a Coroa, a desligar da Capitania de São Paulo (paulatinamente, mutilando-a) as minas e suas repartições. Foram desmembradas de São Paulo, as regiões de Minas Gerais (1720), Rio Grande de São Pedro e Santa Catarina (1738), Goiás (1744) e Mato Grosso (1748). 
P primeiro golpe ocorreu na região das minas de Cataguazes, com a transferência para Vila Rica (Ouro Preto) da Casa dos Quintos e de Fundição, outrora sediadas em Parati. $\bigcirc$ desmembramento efetivou-se em 1720, com a criação oficial da Capitania das Minas Gerais. A partir de então, nota-se a perda contínua de autonomia política, passando a cidade de São Paulo a ter a presença constante de delegados régios, sendo Rodrigo César de Menezes o primeiro deles. Embora a sede do governo se localizasse aí, as atenções foram desviadas para outros pontos. Desde então, os governadores empenharam-se em promover o progresso da mineração em Mato Grosso e Goiás. Quando observamos o número de vilas criadas no período, fica clara a desatenção em relação ao território paulista. Embora a expansão tivesse elevado em muito o número de novos povoados, não havia nenhuma preocupação, por parte da Coroa, de efetivamente controlá-los. Assim, nessa primeira metade do século XVIII, deparamos-nos com uma única situação de elevação de um núcleo à categoria de vila e somente porque a concessão, em 1705, dos foros de vila a Pindamonhangaba foi fruto de uma atitude clandestina de seus fundadores. Sentindo o povoado já em condições de autogerir-se, eles envolveram um desembargador, que estava de passagem, para, na calada da noite, estabelecer juízes e oficiais para a câmara e levantar o pelourinho. A atitude provocou a revolta e protestos de Taubaté, a qual era subordinada a Freguesia de São José de Pindamonhangaba. Alegavam que, sem qualquer Ordem Régia ou provisão do donatário da ainda Capitania de Itanhaém, o ato era ilegal. $\bigcirc$ fato é que, em 1705, a rainha D. Catarina (que substituiu D. Pedro II, gravemente enfermo) acatou o ocorrido, dirigindo Carta Régia, ao Ouvidor de São Paulo, ordenando que novamente se criasse a vila de Pindamonhangaba, após repreender severamente os autores do ato arbitrário. Pindamonhangaba manteve-se como a única vila criada na primeira metade do século XVIII.

Ao contrário da situação supracitada, foi ao sabor de planos e projetos previamente estabelecidos que todo o território da colônia visado pela Coroa foi estruturado. Nas mãos dela, a política de urbanização tornou-se centralizada em territórios que simbolizavam lucratividade e interesse geopolítico ${ }^{53}$, gerando tensões e conflitos com a população local.

Embora esses programas de criação de vilas não dissessem respeito ao território paulista propriamente dito, engendrou nele muitas melhorias e incrementos, em função da necessidade de aperfeiçoar-se continuamente o sistema de comunicação com as novas regiões a ele anexadas. A rede urbana e de caminhos não só se ampliou ao longo do século, como sofreu inúmeras melhorias.

A partir da cidade de São Paulo, uma rede de caminhos irradiava-se em todas as direções (Figura 7).

A descoberta das Gerais coincidiu com o aumento do trânsito no Caminho de Curitiba. Desde os primeiros anos do século, passavam por ele boiadas e tropas de muares, então adquiridas em Curitiba. Era comum também o trânsito de cavalos, produto que, em vista de sua raridade, era extremamente valorizado 


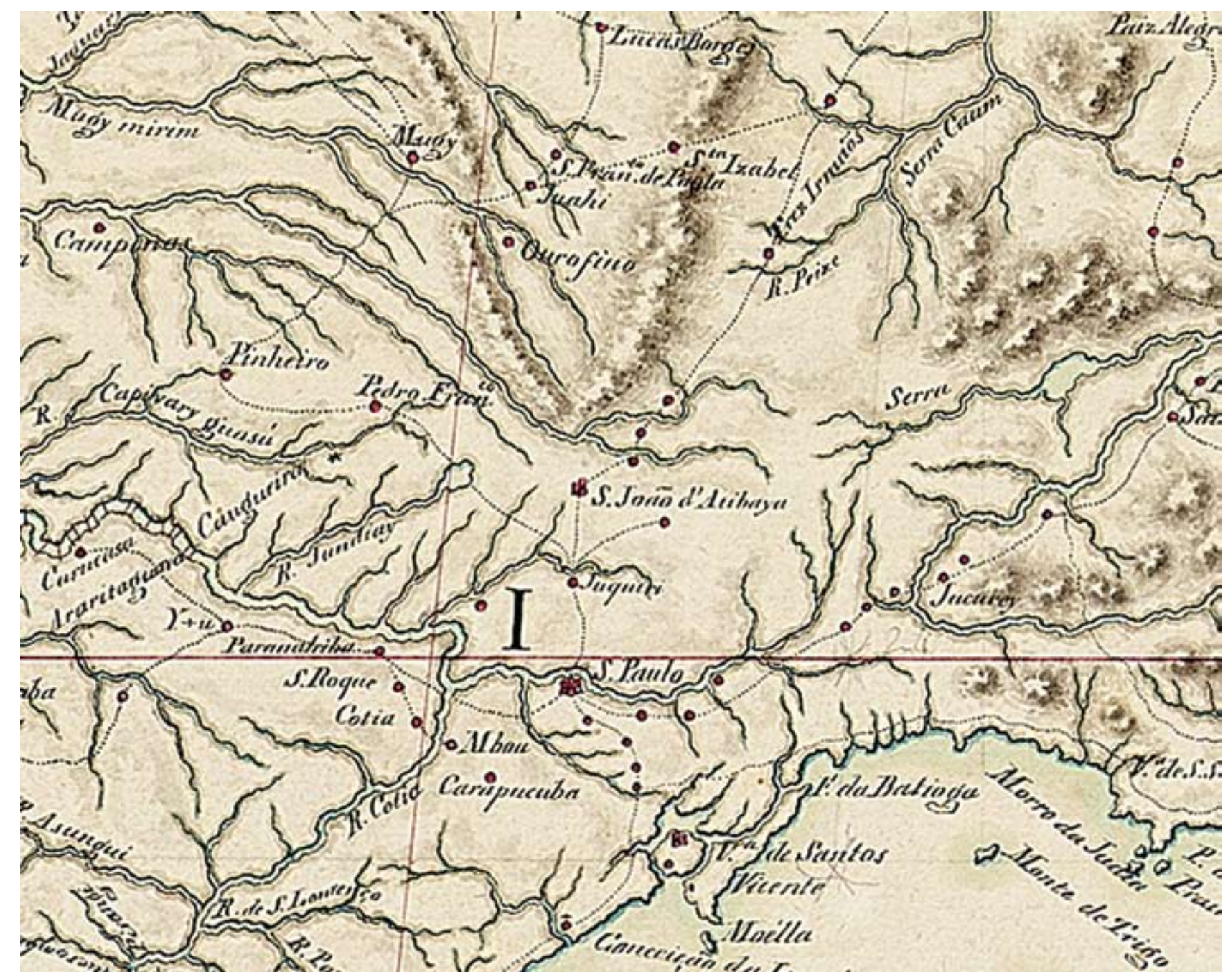

Figura 7 - José Joaquim Freire [atrib.]. Rede urbana, viária e fluvial que irradiava a partir da Cidade de São Paulo. Detalhe de [Carta Geral do Brasil]. [1797]. Escala [ca. 1:2.600.000]. Um mapa em 16 folhas coladas. ms., color. 199cm $\times 202 \mathrm{~cm}$. Direcção dos Serviços de Engenharia, Lisboa.

54. O Caminho do Viamão partia de Viamão, passando por Lages, Lapa, Castro, Itapeva, Itapetininga, Sorocaba, freguesia de São Roque e São Paulo. nos territórios auríferos. Mas as principais estrelas desse comércio que começava a se estruturar eram os muares, criados extensivamente nas regiões dos atuais Uruguai e Argentina, de onde eram exportados para o Peru. Eram produtos especialmente valorizados, pois mais afeitos ao transporte de cargas do que os cavalos. $\bigcirc$ chamado Caminho do Viamão ${ }^{54}$ (Figura 8) ligava o Rio Grande a São Paulo, passando por Sorocaba, último ponto de invernada antes da penetração em mata profunda. A intensificação do trânsito condicionou o calçamento de parte do trajeto e o estabelecimento de registros, onde arrematadores cobravam impostos tanto sobre animais como sobre indivíduos. A descoberta das minas de ouro do Paranapanema e de Apiaí gerou a intensificação do fluxo no trajeto. Ao longo do 


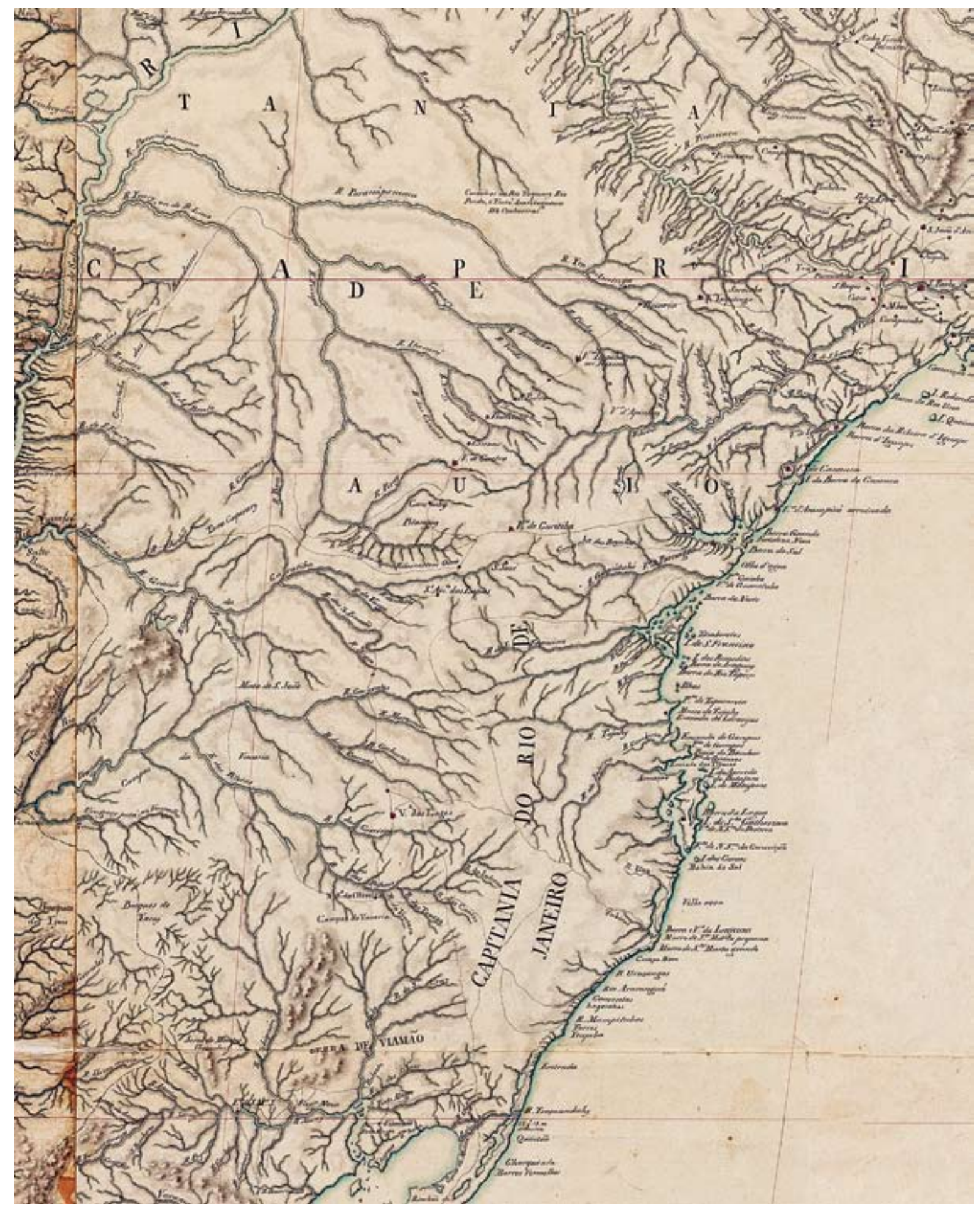

Figura 8 - José Joaquim Freire [atrib.]. O Caminho do Viamão. Detalhe de [Carta Geral do Brasil]. [1797]. Escala [ca. 1:2.600.000]. Um mapa em 16 folhas coladas. ms., color. $199 \mathrm{~cm} \times 202 \mathrm{~cm}$. Direcção dos Serviços de Engenharia, Lisboa. 
55. O varadouro de Camapuã envolvia um percurso terrestre de 14 quilômetros. Cf. V. da Silva (2004, p. 80).

56. Cf. Documentos Interessantes (v. 20, 1896, p. 298).

57. Para a Vila Boa de Goiás, o caminho partia de São Paulo, contornando o Jaraguá, passando por Jundiaí, Campinas, Mogimrim, pelo pouso de Franca e pelos arraiais de Bonfim, Meia Ponte (atual Pirenópolis) e Córrego do Jaraguá.

58. Ver D. M. R. Boaventura (2007). caminho do Paranapanema até Curitiba, foram distribuídas várias sesmarias e estabelecidos arraiais que logo se converteram em freguesias (Apiaí e Paranapanema, em função das minas; Itapetininga, em local despovoado, para estabelecimento de registro, então construído junto do rio de mesmo nome).

A cartografia do período também demonstra a ampliação da rede em direção a Mato Grosso e Goiás. O trajeto para as minas do Mato Grosso era feito pelos rios Tietê e Paraná, ao passo que, para Goiás, era basicamente por terra.

A rota para Cuiabá envolvia trecho de três dias por terra, margeando o rio Tietê, de São Paulo até a freguesia de Araritaguaba (atual Porto Feliz), passando pelas freguesias de São Roque e Araçariguama, e por ltu. Do porto de Araritaguaba, às margens do rio Tietê, próximo a Sorocaba e ltu, partiam as principais provisões dirigidas ao centro-oeste. Desde o século XVII, tal paragem já era utilizada como porto, sobretudo para as rotas do Paraguai. Mas foram as "monções" - expedições por via fluvial para abastecimento das minas de ouro - que intensificaram e dinamizaram o antigo ponto de partida. Ideal na monção de outono-inverno, correspondente ao período de seca (abril-maio - junho-agosto), percorria-se o Tietê em canoas, até o Paraná, de onde se partia em direção ao rio Pardo, e, deste, aos rios Coxim, Taquari, Paraguai, Porrudos e Cuiabá. Com trechos de varaçãa ${ }^{55}$ - em que as canoas eram carregadas pelos indígenas -, o trajeto era sofrido. Um total de 531 léguas, ou 3.504 quilômetros, de Porto Feliz a Cuiabá, tornavam o percurso uma façanha, como podemos constatar no relato de Caetano dos Santos sobre a viagem do governador Rodrigo Cezar de Menezes, em 1728, dois anos após a elevação do Arraial do Senhor Bom Jesus do Cuiabá à condição de vila:

Chegou a estas Minas com viagem de quatro meses, desfigurado, com perdas concideraveis ainda de sua perciza matolotagem, por ser o sertão longevo, áspero, dezabudo, e quasi intrasavel (sic), experimentando os contratempos delle, expondo-se aos contínuos riscos de vida, assim por rezão das feras, e gentios como dos rios, e muitas cachoeiras, e passou as carestias da terra, comprando tudo pêlos preços comuns, a q. voluntário tho queria vender ${ }^{56}$.

O comércio interregional era intenso e encabeçado, sobretudo, por sorocabanos e ituanos, que assim detinham os maiores lucros pelo abastecimento das longínquas minas de Cuiabá e Goiás. Dadas as dificuldades da rota das monções e o tempo longo da viagem, preferia-se o caminho por terra de São Paulo a Vila Boa e, dali, a Cuiabá, passando pelo triângulo mineiro, antiga comarca de Paracatu (Figura 9)

O caminho de São Paulo a Goiás ${ }^{57}$ era todo por terra, passando por Jundiaí, por Mogi do Campo, pelas aldeias do rio das Pedras, de Pissarão, do rio das Velhas e do Lanhozo, por Santa Cruz e Meia Ponte (atual Pirenópolis), até chegar em Vila Boa (atual Goiás Velho ${ }^{58}$. De pousos de sertanistas derivaram importantes núcleos, como Mogi Mirim, Mogi Guaçu, Campinas, Franca e Casa Branca (Figura 10). O caminho velho passava pela região do Triângulo Mineiro, antiga Farinha Podre (atual Uberlândia), com todos os pousos e passagens 


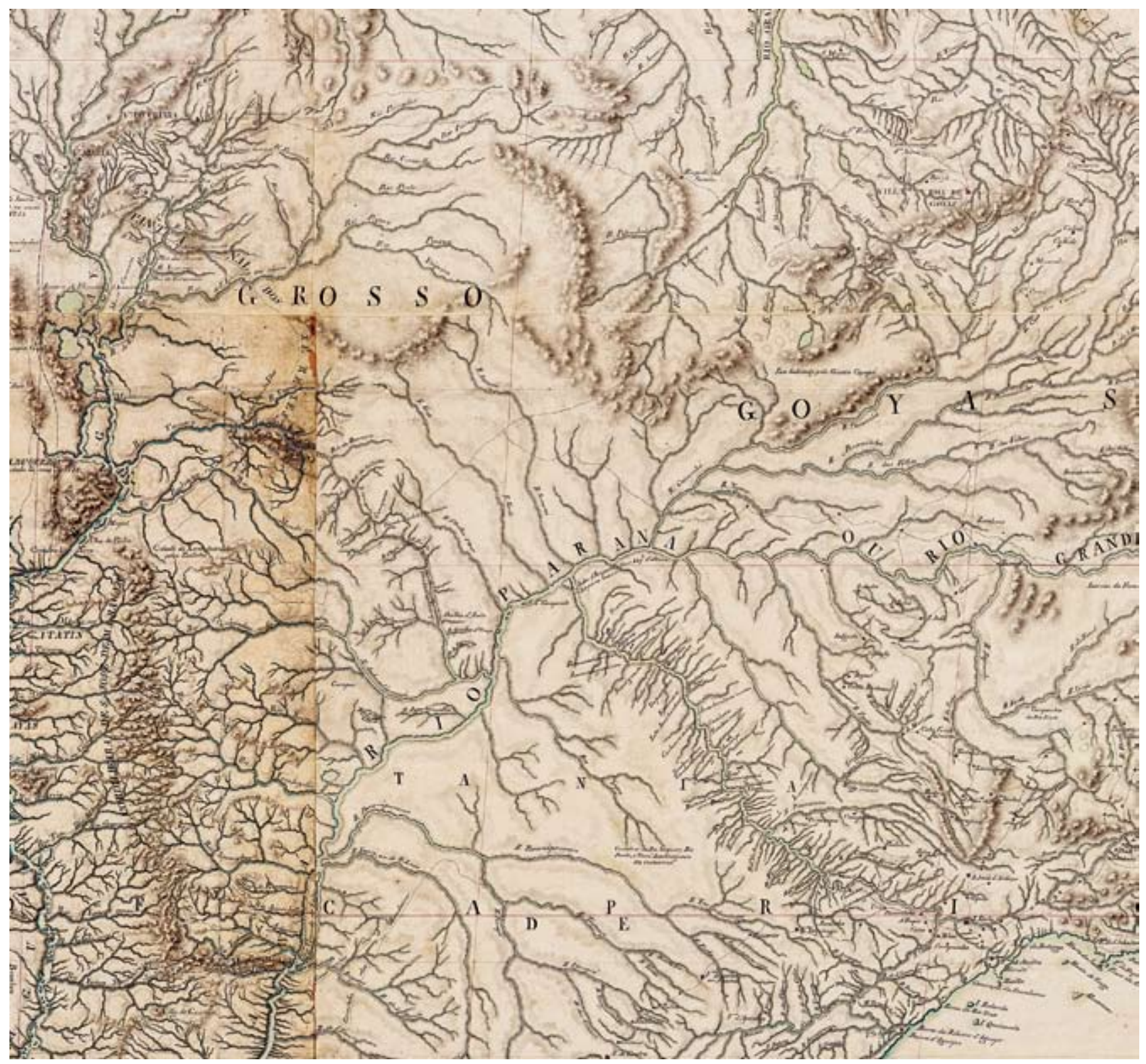

Figura 9 - José Joaquim Freire [atrib.]. A Rota das Monções para Cuiabá. Detalhe de [Carta Geral do Brasil]. [1797]. Escala [ca. 1:2.600.000]. Um mapa em 16 folhas coladas. ms., color. 199cm x 202cm. Direcção dos Serviços de Engenharia, Lisboa.

minuciosamente delineados no mapa de Francisco Tosi Colombina (Figuras $11 \mathrm{e}$ 12). É imprescindivel lembrar que as rotas terrestres eram percorridas em redes ou em mulas, por caminhos não calçados, debaixo de sol e chuva. Boa parte da interiorização se fez com tais meios de transporte ou simples pés descalços.

Podemos dizer, portanto, que na primeira metade do século XVIII, os paulistas contribuíram muito para a estruturação e viabilização dos intentos da Coroa, que continuamente os estimulou a descobrir as famosas minas e a 


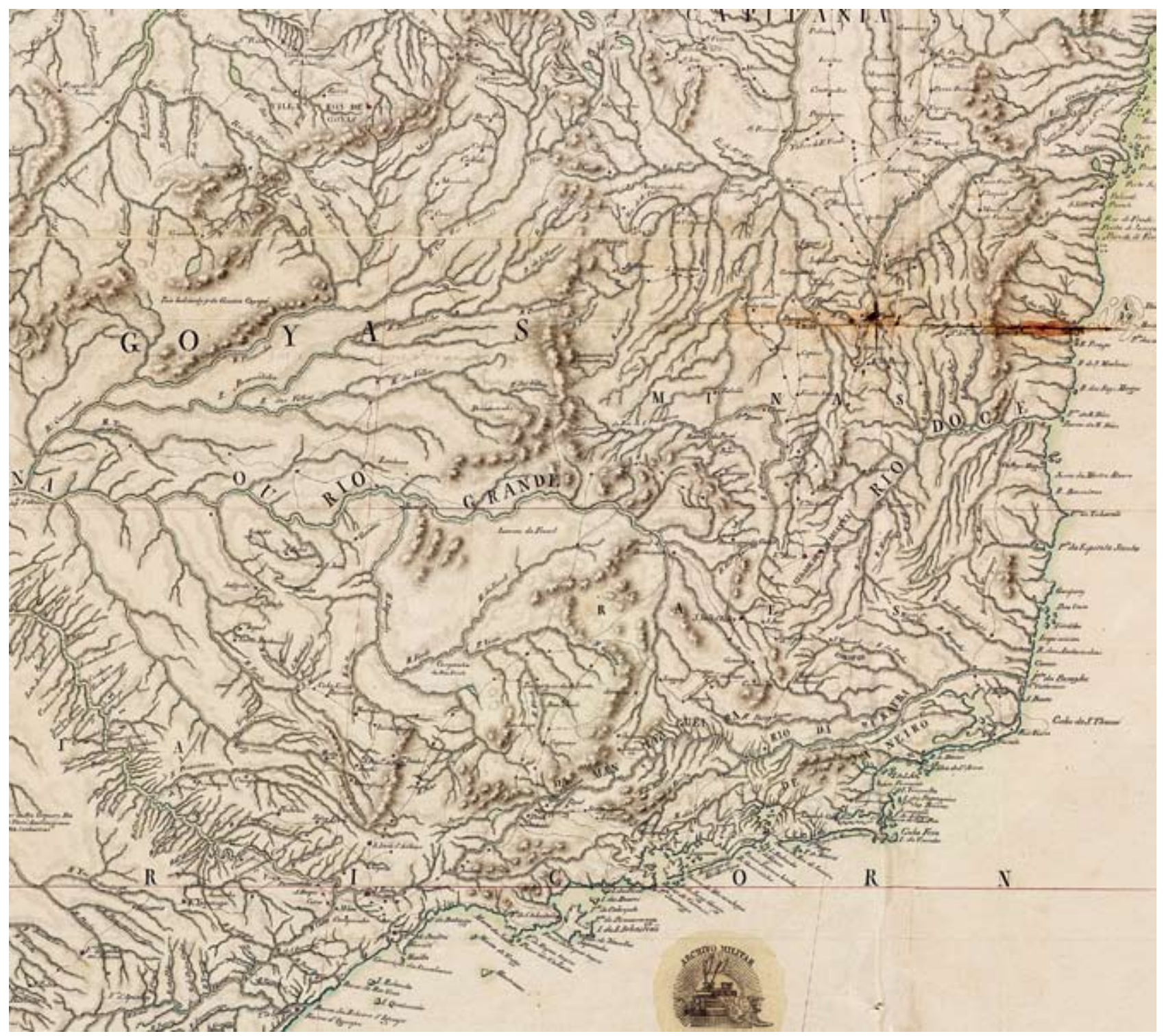

Figura 10 - José Joaquim Freire [atrib.]. O Caminho Velho para Goiás. Detalhe de [Carta Geral do Brasil]. [1797]. Escala [ca. 1:2.600.000]. Um mapa em 16 folhas coladas. ms., color. 199cm x 202cm. Direcção dos Serviços de Engenharia, Lisboa.

59. Ver R. M. de Araújo (2000).

60. Ver I. Blaj (2002); e J. M. Monteiro (1994). interiorizar-se. Mas, estando tão longe, a Coroa não podia continuar controlando o que tanto a interessava. Em 1748, decidiu pela criação da capitania de Mato Grosso 59 , última a ser desmembrada da Capitania de São Paulo, condicionando sua concomitante extinção. A partir de então, esta última deixou de ter governo autônomo, ficando como simples comarca, subordinada à Capitania do Rio de Janeiro. Escapando aos olhos fixos de Portugal, desenvolveu-se ao sabor das circunstâncias ${ }^{60}$ (Figuras 13 e 14). 


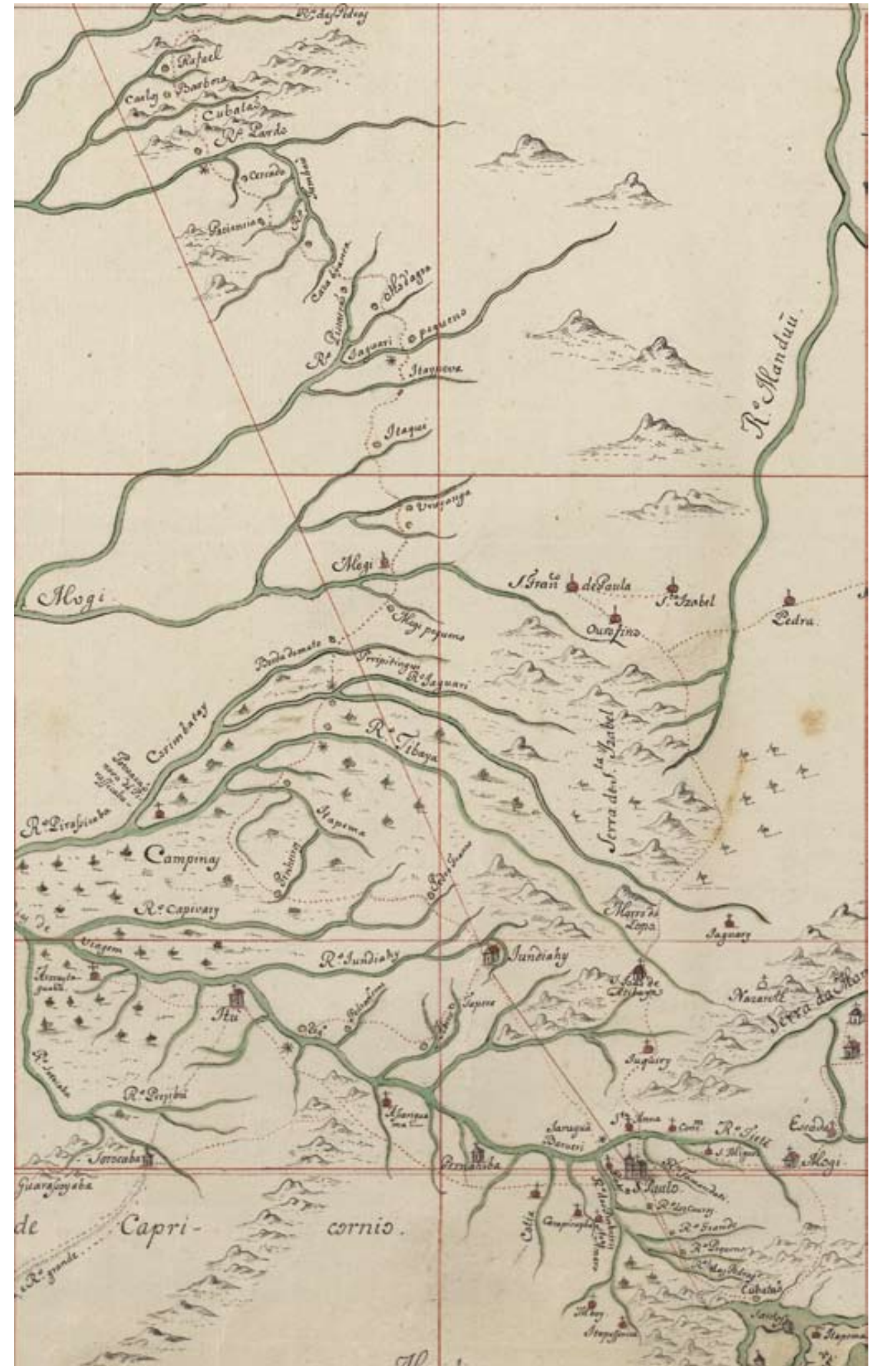

Figura 11 - Francisco Tosi Colombina. O Caminho Velho para Goiás. Detalhe de: Mappa da Capitania de S. Paulo e seu sertão, em que se vem os descobertos, que the foraõ tomados das Minas Geraes, como tambem o Caminho de Goyazes, com todos os seus pouzos, e passagens, deleniado por Francisco Tosi Colombina. Séc. XVIII. Fundação Biblioteca Nacional, Rio de Janeiro. 


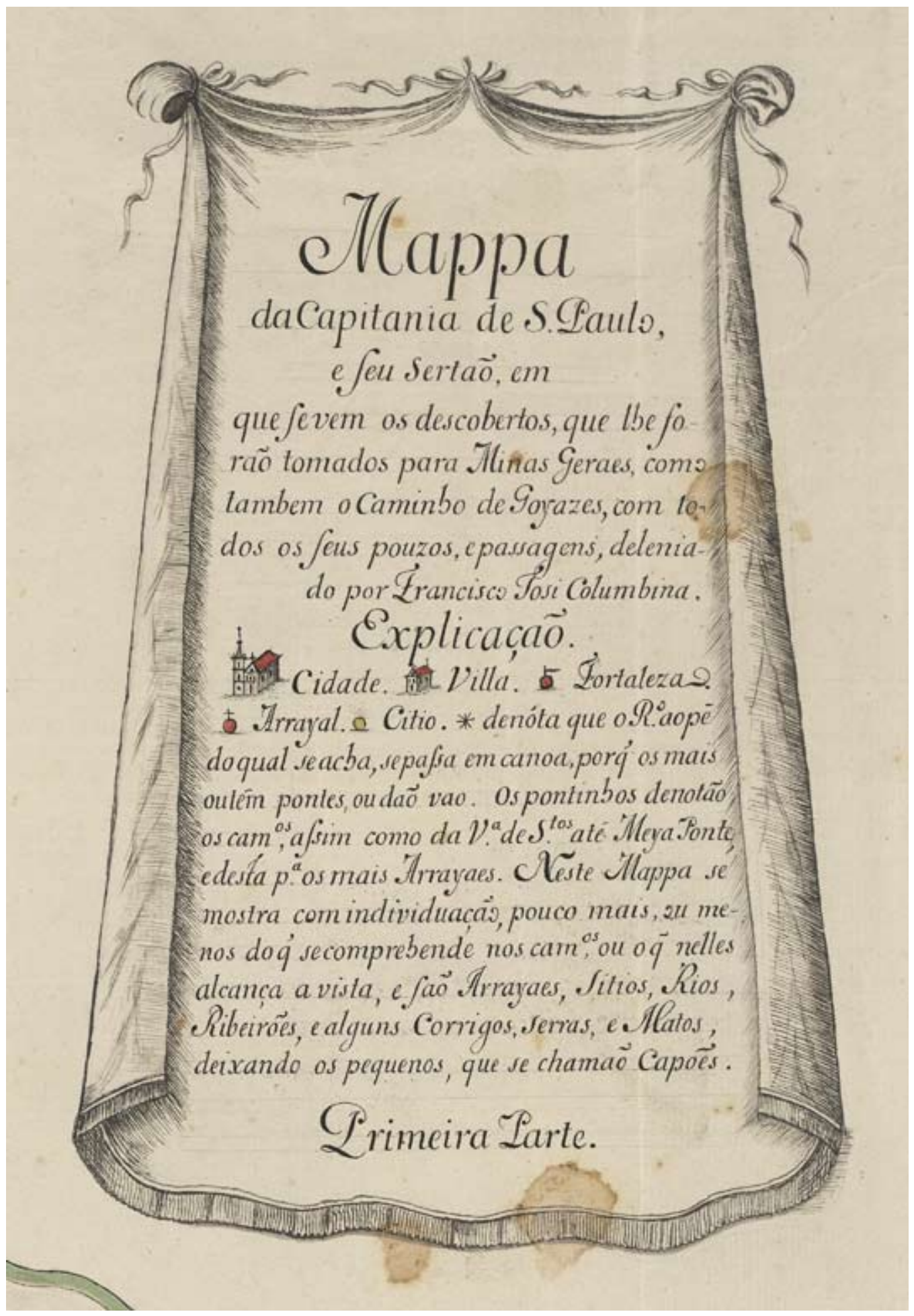

Figura 12 - Legenda do Mappa da Capitania de S. Paulo e seu sertão..., de Francisco Tosi Colombina. 


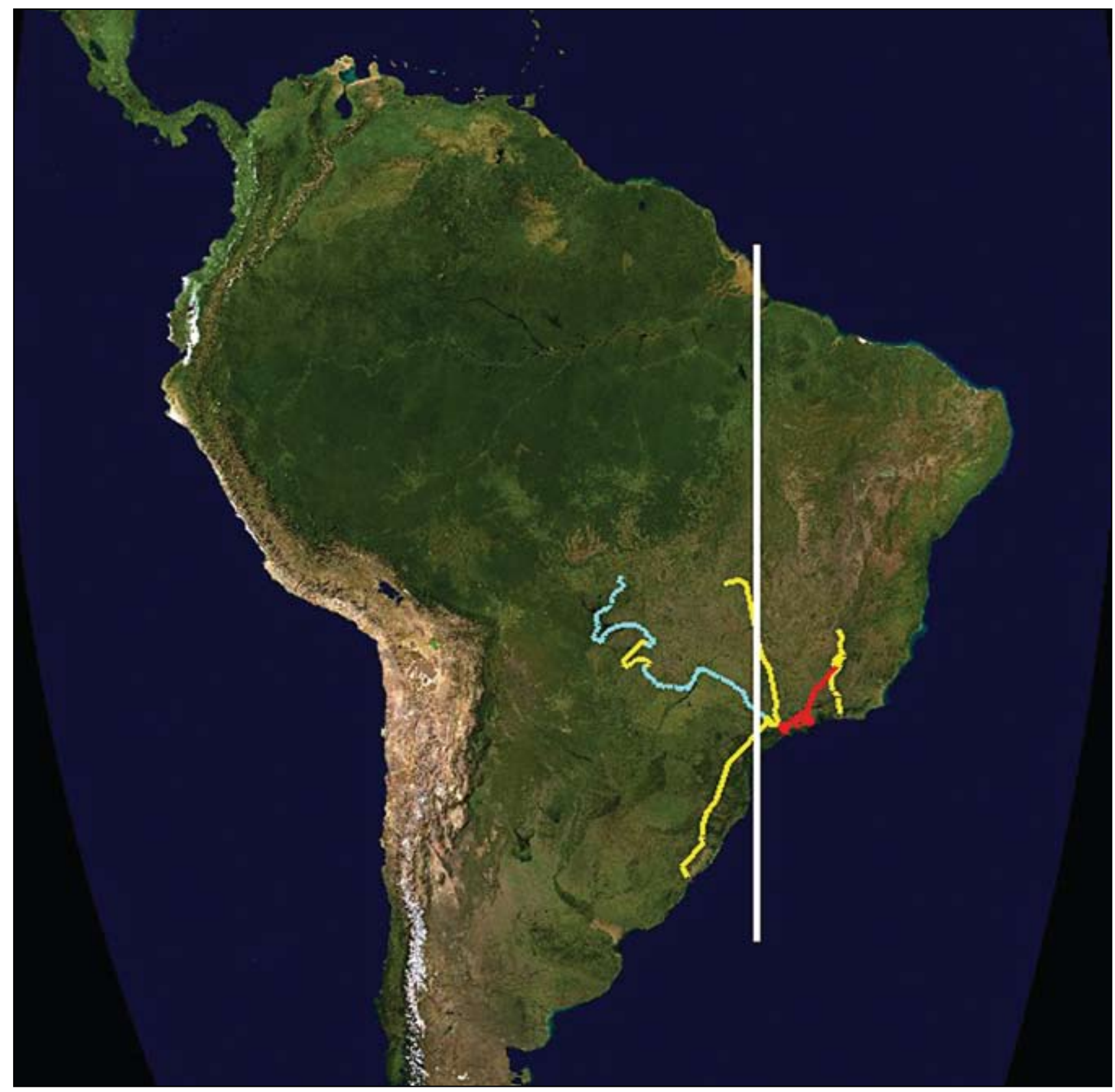

Figura 13 - Os exercícios de reconstituição, baseados em mapas por satélite, da rede urbana, viária e fluvial da Capitania de São Paulo e Minas do Ouro, entre 1711 e 1765, feitos em parceria com o INPE, revelam a imensa área além Linha de TordesiIhas ocupada em solos espanhóis, cabendo ao Tratado de Madri, assinado em 1750, acordar a posse efetiva. Instituto de Pesquisas Espaciais (INPE), São José dos Campos. 
Figura 14 - Georeferenciamento, baseado em mapa por satélite da rede urbana, viária e fluvial da Capitania de São Paulo e Minas do Ouro, entre 1711 e 1765, além Linha de Tordesilhas. Instituto de Pesquisas Espaciais (INPE), São José dos Campos.

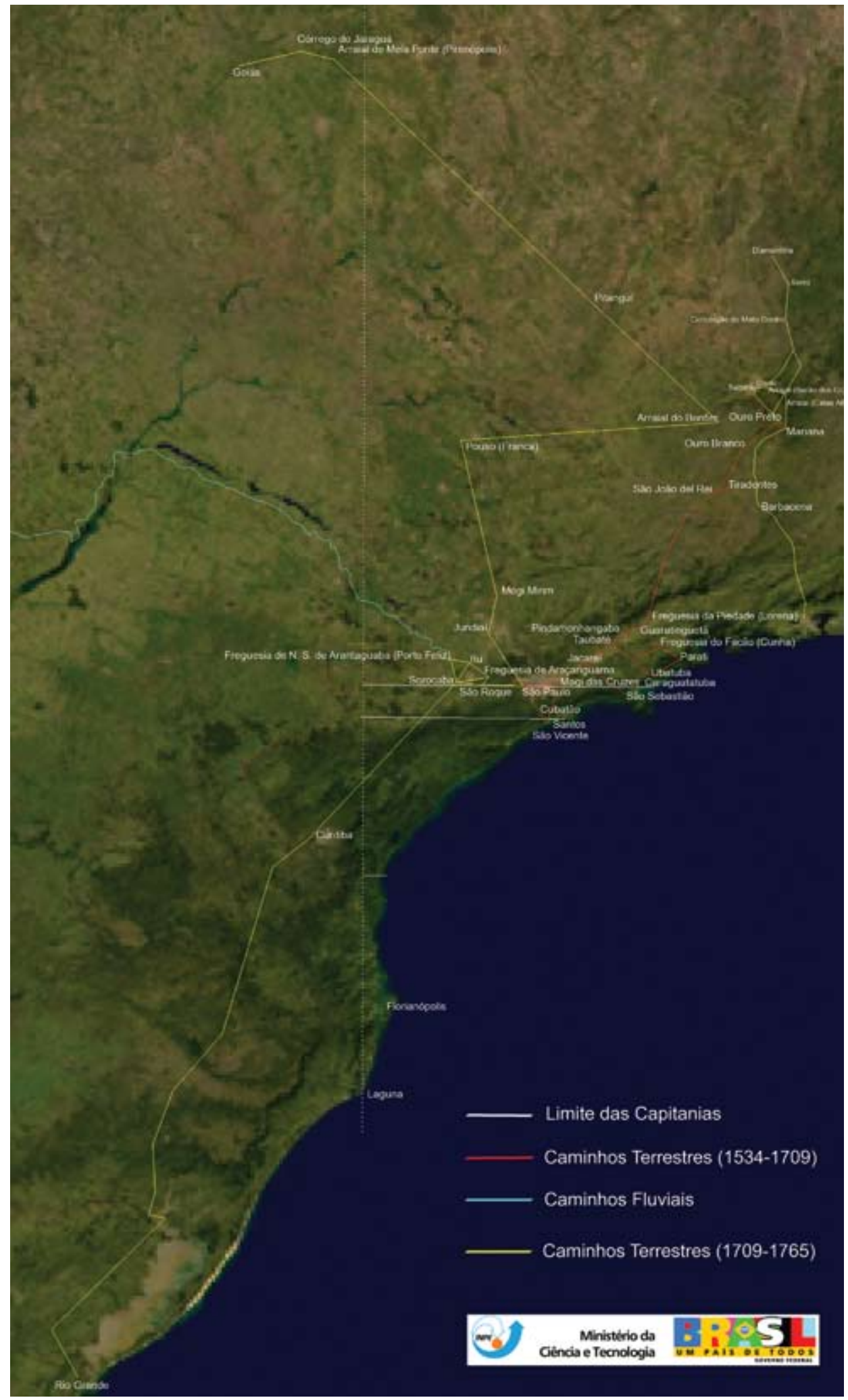

Anais do Museu Paulista.v. 17.n.2. jul.-dez. 2009. 
As grandes desculpas para a restauração da Capitania de São Paulo, em 1765, dezessete anos após a sua extinção (1748), foram razões ligadas ao fisco bem como à solução de questões geopolíticas. As condições de São Paulo e do Brasil na segunda metade do século XVIII inviabilizavam uma administração à distância e alienada de suas necessidades.

No sul, as hostilidades espanholas condicionaram a concentração das atenções de Lisboa nessa região. Aos olhos da Metrópole, em meados do século $\mathrm{XVIII}$, as capitanias centrais e sulinas representavam grandes desafios. Entre eles, destacava-se a necessidade de organizar uma ação bélica no rio da Prata, contra as ofensivas espanholas. Os pontos nevrálgicos eram a Colônia do Sacramento e as proximidades da lagoa dos Patos. Era necessário manter soberania e controle sobre a vasta extensão de terras que os sertanistas paulistas haviam dilatado além Linha de Tordesilhas. A questão dos limites manteve-se em pauta desde o início do século XVIII'bl.

As autoridades hispano-americanas vinham procurando impedir essa irradiação luso-brasileira que fora se processando ao longo dos últimos dois séculos. O esforço maior concentrou-se nas mãos dos jesuítas a seu serviço. Esses, ao estabelecer reduções, foram paulatinamente criando uma linha de fronteira perfeitamente organizada, inclusive militarizada. Os jesuítas utilizavam-se de contingentes indígenas preparados nas missões. Em contrapartida, o esforço ou a intenção portuguesa visava à manutenção de toda a área geograficamente acrescentada. A expansão não podia ser sacrificada com algum recuo que importasse em perdas substanciais de territórios descobertos - que, agora, constituíam um campo de exploração econômica definida e necessária aos mercados coloniais e metropolitanos portugueses. Nesse particular, desde o reinado de D. Pedro II, houve um propósito oficial português ao se negociar o ajuste entre Portugal e Espanha no controle do Prata, reconhecendo a Espanha, momentaneamente, o direito português de ali manter posição. A colonização dos territórios sulinos impediu o avanço espanhol e deu cobertura à interiorização dos sertanistas. Os portugueses, paulatinamente, ocuparam a região do Rio Grande de São Pedro, onde já se fazia, desde a primeira metade do século XVIII, um intenso comércio de gado bovino, equino e muar; e onde paulistas realizavam contínuas incursões. No entanto, em 1735, partindo de Buenos Aires contra a Colônia de Sacramento, um ataque espanhol fez renascer o conflito. Somente as negociações e o estabelecimento do Tratado de Madri, em 1750, puseram momentaneamente fim ao novo período de crise de limites. Baseado no principio do uti possidetis, solucionou-se parcialmente o litígio. O Brasil realizado geograficamente pelos sertanistas paulistas, pelos sertanistas do norte e pelos religiosos a serviço do Estado era, agora, legitimamente reconhecido pela Espanha. Assim, foi acordado que os luso-brasileiros permaneceriam nos trechos 
62. Idem.

63. Idem.

64. Ver F. J. C. Falcon (1982)

65. Cf. N. G. dos Reis Filho (1995, p. 44-56). do território onde já haviam se estabelecido, valendo o mesmo para os hispano-americanos. No início do governo de D. José I e do futuro marquês do Pombal, seu primeiro ministro, iniciaram-se os trabalhos de demarcação. Os jesuítas do sul colocaram obstáculos para a trégua, o que levou, em 1761, à anulação do Tratado (Tratado de El Pardo). Em consequência disso, Pombal decidiu promover um povoamento mais intensivo em certos trechos da fronteira. Foi elaborada assim toda uma política de urbanização, com características específicas em cada região do território brasileiro. No que tange à Capitania de São Paulo, então programaticamente restaurada, coube a D. Luís Antonio Botelho Mourão, Morgado de Mateus, governá-la (1765-1775)62.

Em 1763, a sede do Governo Geral foi transferida para a Cidade de São Sebastião do Rio de Janeiro, tendo, em seguida, ocorrido a restauração da Capitania de São Paulo (1765). A região sul da colônia tornara-se importante centro econômico e estratégico-militar. A restituição da autonomia a São Paulo não obedeceu apenas a uma necessidade geral, geopolítica e administrativa la defesa do sul e do oeste, dada a impossibilidade do Rio de Janeiro de responder por tudo), mas também atendia a uma necessidade local e econômica. Além de pôr fim aos atritos sulinos, a metrópole, mais uma vez, buscava novas fontes econômicas, em vista do escasseamento da produção aurífera a partir de meados do século XVIII. Passava-se à revalorização das áreas com potencial agrícola, independentemente do ouro. São Paulo, a não ser nas pequenas manchas da lavoura de subsistência, era campo virgem e aberto a um possível renascimento da agricultura. Na segunda metade do século XVIII, a economia portuguesa apresentava um quadro bastante difícil. A sua feição, na primeira metade da centúria, era de estabilidade, mas a situação agravou-se, principalmente a partir de 1772, com a crise do ouro brasileiro. Segundo Heloísa Belotto ${ }^{63}$, à frente de um império grande demais para sustentar-se, com o território metropolitano culturalmente viciado pelo jesuitismo, carente demográfica e economicamente, Pombal tentou resolver a crise com um reforço do fisco, com reformas de toda a ordem e com o aumento do poder central. A luta, em Portugal, seria pela indústria, contra a mentalidade impregnada do jesuitismo, contra o domínio inglês no comércio externo, contra o abandono da terra; na colônia, contra o desleixo no fisco, contra o contrabando e pelo incentivo à agricultura. Os elementos fundamentais do projeto pombalino ${ }^{64}$ concentraram-se no fortalecimento do poder central. Uma dos meios para alcançá-lo foi o afastamento dos nobres que ocupavam posições destacadas, aliando-se à burguesia mercantil favorecida pelos monopólios e pelas Companhias de Comércio. Outra medida tomada foi a expulsão dos jesuítas (1759) e a consequente secularização das missões. Para recuperação econômica do Estado, Pombal decidiu pela revitalização da agricultura, criação de companhias de comércio e estímulo à indústria. No Brasil, as medidas centralizadoras concretizaram-se na extinção das capitanias donatárias, no reforço das fronteiras e na mudança da capital para o Rio de Janeiro65, e pelo estímulo à agricultura - política empreendida por governadores ilustrados, enviados estrategicamente para cada uma das capitanias. 
Um corpo fundamental de instruções de Pombal, constituído por duas Cartas Instrutivas, ambas datadas de 26 de janeiro de 1765 e dirigidas respectivamente ao Morgado de Mateus e ao Vice-Rei conde da Cunhab6, nortearam os rumos da então restaurada Capitania de São Paulo. A meta do novo governador da capitania, o Morgado de Mateus, concentrava-se na defesa do território, no combate aos espanhóis, no preparo militar necessário para tanto e na expulsão dos jesuítas (efetuada em 1759) - que, no entender da Coroa e de Pombal, estavam implicados nas usurpações territoriais e na manipulação dos índios. Quanto à preparação bélica, chamava novamente à luta o brio dos habitantes de São Paulo. Criou-se assim ambiente propício para a arregimentação de tropas de milícias ou tropas de ordenanças, que os graduasse nos vários postos, de modo que estes "se fação apiticiveis a vaidade dos moradores principaes daquella Capitania"67.

Além dos paulistas, o governo central pensava no aproveitamento dos índios, eles "devião constituir a principal força e a principal riqueza para nos defendermos nas mesmas Fronteiras"68.

Quando extinta, a Capitania de São Paulo sobrevivera ${ }^{69}$ graças a seu inter-relacionamento com as regiões vizinhas, assegurado pelas "monções" e pelo tropeirismo, nas respectivas rotas do Cuiabá e do Viamão. No que tange à agricultura, embora restrita e acanhada, ela ocupava metade da população, dedicada sobretudo à lavoura de subsistência. A agricultura era realizada à maneira indígena, no sistema de sítios volantes, e visava, quando não à própria subsistência, ao abastecimento dos núcleos urbanos e dos tropeiros. Embora incipientes, essas várias formas de comércio tinham propiciado a infraestrutura econômica que possibilitou a obra do Morgado de Mateus. A política do governador visava justamente a dinamizar essa infraestrutura. No planalto e no litoral, foi estimulado o plantio da cana-de-acúcar, que prosperou na região de Itu, Campinas e Piracicaba e no litoral norte, especialmente em llha Bela.

Na base da política de urbanização empreendida pelo Morgado de Mateus, estiveram a necessidade de criar tropas de milícias, associada à de dinamizar toda uma engrenagem que se estabelecera espontaneamente. Era preciso dinamizar o mercado interno, que esboçava um enorme potencial. Era preciso agrupar a população dispersa. A política de Pombal enquadrava a capitania na engrenagem do todo, mas, pela primeira vez, esboçava uma preocupação com o desenvolvimento do seu próprio território. Os governadores anteriores à extinção da capitania pouco permaneciam em território paulista e, mesmo estando aí, tinham os olhos voltados para as regiões do ouro. A Capitania era agora, pela primeira vez, objeto de um programa que a beneficiava. Nesse sentido, estes dez anos foram importantíssimos para a história de São Paulo, convertendo-se em ponto fundamental de manutenção de uma parte essencial do território brasileiro - o sul e o oeste.

Como vimos, entre 1705 e 1767, nenhuma vila foi fundada em território paulista. Em seus primeiros tempos, os reinados de D. João $V$ e o de D. José I estiveram voltados exclusivamente para as zonas de mineração. Não houve
66. Ver Oficio do Morgado de Mateus ao Conde de Oeiras. São Paulo, 23 de dezembro de 1766. In: Documentos interessantes (v. 23, p.4).

67. Idem, ibidem.

68. Idem, ibidem.

69. Ver I. Blaj (2002); J. M. Monteiro (1994). 
70. Ver Avisos e Cartas Regias. Arquivo do Estado de São Paulo: lata 62, n. 420 , Livro 169.

\section{Idem, p. 145}

72. Ver Carta do Morgado de Mateus à Camara de Iguape. São Paulo, 12 de Janeiro de 1767. In: Documentos Interessantes (v. 67, p. 76)

73. Ver Bando para que nenhuma pessoa possa dezertar dos citios em que viverem. Santos, 25 de Fevereiro de 1766. In: Documentos Interessantes (v. 65 , p. 48-49) necessidade de expandir a rede urbana do século XVII; ou sequer interesse nisso. Sem dúvida, tal aspecto é o que chamamos de prova concreta do descaso da política metropolitana em relação à Capitania. O próprio Morgado de Mateus o constataria. Ao enviar a descrição do Estado Político da Capitania, após um ano e meio de governo, assim comentou a respeito das antigas vilas:

As Vilas e Povoações Civis que tem esta Capitania quaze todas as fundarão os primeiros povoadores; aquellas de que pude alcançar a sua fundação quaze todas forão feitas no tempo dos donatários, e antes do descobrimento das Minas; a última que se fundou foi Pindamonhangaba, a qual foi feita Villa por ordem de Sua Magestade de dez de julho de mil setecentos e cinco; tudo consta dos papéis antigos do Archivo desta Camara; desde esse tempo para cá não houve mais fundação alguma; porém algumas Villas são Povoações muito pequenas; os mesmos moradores que nellas se conservão são os que tem citio mais perto, porque os que tem longe só acodem à Villa pelas festas do anno, ou em solenidades mayores, fora destes cazos vão seguindo o mato virgem ${ }^{70}$

Dentro dos propósitos a que viera, o Morgado de Mateus compreendia que uma urbanização mais densa facilitaria os planos propostos para a restauração, seja do ponto de vista militar, econômico, políitico ou social. Foram constantes as determinações régias contra a dispersão e vinham, sobretudo, ao encontro das finalidades de recrutamento e urbanização. Desde os primórdios da descoberta do ouro, a perseguição aos vadios tornou-se uma constante. Era necessário um maior controle da população e de suas atividades, mas, agora, os interesses vinculavam-se às necessidades de recrutamento em face de um eventual conflito com os espanhóis no sul:

Aos vadios e facinorozos que vivem como feras, separados da sociedade civil e do comercio Humano, era ordenado que abandonassem os 'sítios volantes' e escolhessem lugares accomodados para viverem juntos em Povoações Civis que pelo menos tenhão cincoenta fogos para cima $^{71}$.

Não poderiam desenvolver-se os interesses de Sua Magestade sem se multiplicarem os Colonos, de que há falta grande, e para que os poucos que há possa fazer bom uzo e melhor utilidade, hé precizo congregalos o mais que se puder, em Povoações Civis, fundando-se de novo, e acrescentando aquela que já temos, porque sem isso nem pode haver commercio nem riqueza permanente ${ }^{72}$.

Para evitar a dispersão, que em muito prejudicava o recrutamento, ordenou-se que ninguém deixasse o local de moradia, sem licença superior ${ }^{73}$

Os índios também foram alvos dessa política. Deviam ser congregados em aldeias, fossem elas do Padroado Real (Pinheiros, Barueri, São Miguel, Nossa Senhora da Escada, São João dos Guarulhos) ou antigos núcleos jesuítas (São José, Nossa Senhora da Ajuda, Mboy, Carapicuíba e ltapecerica).

As primeiras providências foram tomadas em 1766 :

Desejando dar providencia sobre a falta que ha de Povoações civis nesta Capitania, tenho 
disposto mandar formar seis em diferentes partes que me pareceram as mais próprias, e as mais úteis pela sua cituação, comodidade, e fertilidade do Paiz, e são as seguintes: Huma na Barra que faz o Rio Pirassicaba entrando no Tietê, dez legoas mais adiante de Araytaguaba, última povoação em que se embarca para Cuiabá, para que os que fazem esta viagem tinhão escalla mais abayxo em que possão refazer-se [...] Outra no Wotucatu, sobre o Rio Paranapanema para tentar-se poder restaurar as muitas fazendas que se despovoarão naquelle Rio depois que abandonamos a navegacão delle para Cuiabá, pertendo [sic] juntamente as vargens da Vaccaria de Guaycuru de que hoje se querem fazer senhores os casteIhanos [...]; Outra na paragem chamada a Faxina sobre o caminho que vay de São Paulo para Curitiba adiante de Sorocaba que hé a ultima villa, quarenta legoas para ver se acrescentão para aquella parte mais as povoações por não haver em toda a distancia daquella Villa até Curitiba [...]em que só tinha alguns moradores [...] Outra nos Campos de Lagens/ em legoas depois de Curitiba no caminho que vay para Viamão, para ver se juntão os muitos moradores dispersos que ha de parte de cima da serra da Costa do Mar, fazendo-se fortes sobre as margens do Rio Pelotas para fortificar aquella paragem contra invazões que ahy podem fazer os Índios das missões castelhanas, cortando-nos com muita facilidade o passo e comunicação que possamos ter por terra com os habitantes de Viamão [...] Outra na costa do mar na enseada de Guaratuba abayxo de Paranaguá para o Sul dés legoas por ser bom Porto de mar muito farto de peixe, e excelentes terras [...] Outra no Rio Sabaúna entre lguape e Cananeia por ser bom porto do mar, muito farto de peixe, e boas terras, e desejar que todos os Portos desta Costa se povoem [...] De todos estes lugares mandarei a V. Exº̣ a carta chorografica logo que a puder concluir e ajustar para ir com a exactidão, a qual eu mesmo ey de fazer, e pintar por não ter quem saiba ${ }^{74}$.

Em 1767, a aldeia de São José do Paraíba latual São José dos Campos) foi elevada à categoria de vila: "Portanto Sua Mage foi servido ordenarme nas Instruções [...] e em outras ordens que fui recebendo, que era muito conveniente ao seu Real serviço que nesta Capitania se erigissem Villas nas Aldeias dos índios, e que todos os vadios e dispersos, ou que vivem em citios volantes se congregassem em Povoações Civis"75.

Em 1769, foi a vez de São João de Atibaya ${ }^{76}$ e Mogimirim:

Foi servido ordenarme [...] que nesta Capitania se erigissem Villas aquellas povoações que fossem mais próprias para o ditto efeito, e porque huma das mais que se distinguem em os requizitos necessários para receberem a honra do nome de Villa hé a Povoação de São João de Atibaya [...] Por ter capacidade e suficiência para se augmentar em mayor povoação pelo tempo adiante do que a Freguesia de Mogi-guaçu, cuja situação era muito húmida e com pouco extracção para se povoar, sendo esta de Mogimirim hum plano seco em se podião estabelecer cazas e terem mayor duração [...] Por ficar este lugar de Mogimirim quatro dias de jornada de caminho rigorozo, de passagens de rio distante daquella Villa de Jundiahy ${ }^{77}$.

Segundo Heloísa Belotto, nos primeiros anos de governo do Morgado de Mateus, nas tentativas de estabelecer povoações, o objetivo era preponderantemente estratégico. Lages, Faxina e Itapetininga estavam dentro da meta de colonização do roteiro do sul, visando a preservar e a dinamizar uma
74. Ver Cartas ao Conde de Oeiras sobre povoações da Capitania. In: Documentos Interessantes (v. 23, p. 40).

75. Ver Documentos Interessantes (v. 23, p. 398; 418).

76. Ver W. F. da Silveira (1950).

77. Ver Documentos Interessantes (v. 34, p.150-202). 
78. Ver M. Neme (1943).

79. Ver Documentos Interessantes (v. 4,, p. 104)

80. Ver Documentos Interessantes (v. 23, p. 415).

81. Ver H. L. Belotto (2007). das mais importantes rotas do século XVIII, assegurando a área de domínio daquelas paragens. Era preciso fixar o povoamento ao longo do Caminho do Viamão e controlar o poder dos mandatários locais. Nesse mesmo objetivo se enquadravam Sabaúna e Guaratuba, visando a garantir a defesa do litoral sul, zona vulnerável às aproximações espanholas. Serra acima, Piracicaba ${ }^{78}$ foi destinada a beneficiar o comércio com os monçoeiros que se dirigiam ao Mato Grosso; mas, além disso, associava-se ao empreendimento que o Morgado desenvolvia na região do rio lguatemi - ponto estratégico da defesa contra os espanhóis no território hoje conhecido como Mato Grosso do Sul. D. Luís Antonio visava a estabelecer "uma boa povoação e conseguir a abertura do caminho para o Ivai" ${ }^{\prime 79}$. Tratava-se de um projeto absurdo, do qual, aliás, desistiria pouco depois.

Muitas das localidades prosperaram, chegando a ser elevadas à categoria de vila. Muitas permaneceram como capelas ou simples freguesias, tendo sua situação sido definida em época posterior ao governo do Morgado de Mateus.

Embora pareça fácil, inúmeras correspondências oficiais do Morgado de Mateus expressam queixas relativas à dificuldade de se fundar povoações na Capitania de São Paulo:

Não há couza tão útil, e necessária, como Povoações, principalmente nesta Capitania que hé muita falta. Não ha couza ao mesmo tempo tão difficil. Não fallo nas difficuldade de mover os novos habitadores, que huns não querem, outros pedem o que não ha, outros chorão, outros se escondem, que tudo isso vence, fallo nas muitas vontades que é precizo conciliar para uma couza tão justa, e necessária, e com as quaes não podem as minhas forças, nem me hé possível obriga-las ${ }^{80}$.

É possível estabelecer, grosso modo, os seguintes rumos de expansão da rede urbana paulista no último quartel do século XVIII. Segundo Belotto ${ }^{81}$, na direção sul (correspondendo à defesa e colonização do Caminho de Viamão e do litorall), ainda que em sua forma incipiente, o Morgado de Mateus promoveu a integração territorial, procurando unir os Campos de Vacaria ao eixo Rio-São Paulo-Minas. Era também essa a rota terrestre para as expedições militares que iam combater os espanhóis no Rio Grande. Também nesse mesmo rumo estava o interesse ligado aos sertões do Tibagi e aos Campos de Guarapuava. Se Curitiba era o centro de arregimentação de gente e irradiação das expedições para aquela região, Santa Ana de lapó (vila de Castro), por exemplo, localizava-se entre aquele centro e a região do Tibagi.

Na direção sul, constam os seguintes núcleos urbanos elevados à condição de vila: Faxina; Itapetininga; Santo António das Minas do Piai (Apiaí); Santo António da Lapa do Registro de Curitiba (atual Lapa); Nossa Senhora dos Prazeres de Lages; Santa Ana do lapó (atual Castro); e São Roque. No litoral: freguesia de São José da Marinha de Ararapira; Vila Nova de São Luís de Guaratuba; e N. S. da Conceição da Lage (Sabaúna), defronte da barra do rio 
Sabaúna, entre as vilas de lguape e Cananéia. Na direção norte, a sucessão dos aglomerados urbanos obedeceu uma política de assegurar as fronteiras com as Minas Gerais, região sempre turbulenta e em litígio. Também garantiu as imediações da rota para Goiás. As novas vilas foram: São João Batista de Atibaia; São José de Mogimirim; e freguesia de N. S. da Conceição das Campinas do Mato Grosso de Jundiaí (depois vila de São Carlos, atual Campinas) ${ }^{82}$. Na direção do Rio de Janeiro, aparecem quatro centros urbanos em pleno vale do Paraíba, na região montanhosa que levava ao litoral, junto do porto de São Sebastião: São José do Paraíba (atual São José dos Campos); Nossa Senhora da Escada (atual Guararema); São Luís e Santo Antonio do Paraitinga ${ }^{83}$ (região por onde se burlava a proibição de transitar ao longo da estrada Cunha-Parati, na época do Caminho Novo); Caraguatatuba; Santo Antonio de Paraibuna loutro ponto de acesso ao litoral que merecia controle). Junto a Araritaguaba (atual Porto Feliz), cuja principal finalidade, seria o abastecimento das expedições para o Iguatemi: Piracicaba. Num ponto mais longínquo da direção Tietê-Paraná, estava a povoação de lguatemi, anexa à fortaleza de mesmo nome, hoje município vizinho à Amambaí (Mato Grosso do Sul).

Os documentos referentes ao período evidenciam ainda uma enorme preocupação em relação ao traçado urbano, o que só vem a reforçar, em nível mais específico, a centralização e o controle que, no momento, efetuava-se em todos os sentidos. Aparecem evidentes preocupações quanto às normas de traçado ortogonal das novas vilas fundadas, bem como quanto à própria disposição dos edifícios:

Porquanto tenho encarregado a Francisco Barreto Leme formar uma povoação na paragem chamada Campinas do Mato Grosso, distrito de Jundiaí, em sítio onde se achar melhor comodidade e é preciso dar norma para a formatura da referida povoação. Ordeno que esta seja em quadras de 60 ou 80 varas cada uma, e daí para cima e que as ruas sejam de 60 palmos de largura, mandando formar as primeiras cazas nos angulos das quadras, de modo que fiquem os quintaes para dentro a entestar uns com os outros ${ }^{84}$.

E porque huma das couzas que as Naçoens mais cultas costomão ter grande cuidado no tempo prezente hé a semetria, e armonia dos edifícios que de novo se levantão nas Povoações das Cidades, e Villas para que da sua disposição não resulte a commodidade publica mas também o agrado com que se fazem mais appeteciveis, e habeis as povoações, conhecendo-se da sua boa ordem com q'estão dispostas a policia, e a cultura dos seus habitadores ${ }^{85}$.

relatório apresentado pelo engenheiro José Custódio de Sá e Faria

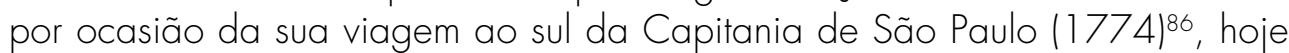
guardado no Rio de Janeiro, na Mapoteca do Itamaraty, revela o descompasso entre a teoria e a prática. Muitas foram as dificuldades do Morgado de implantar os núcleos nas condições desejadas. A correspondência oficial entre o governador e o Conselho Ultramarino (Lisboa, Arquivo Histórico Ultramarino), o governador e o vice-rei (São Paulo, Arquivo do Estado), e o governador e os capitães-mores das vilas (Rio de Janeiro, Seção de Manuscritos da Biblioteca Nacional) revela as
82. Ver A. da C. Santos (2002).

83. Ver L. Saia.

84. Celso Maria de Melo Pupo $(1969$, p. 45$)$

85. Cf. Documentos Interessantes (v. 65, p. 106).

86. Ver outro artigo da autora no presente dossiê, Do borrão às aguadas: os engenheiros militares e a representação da Capitania de São Paulo. 


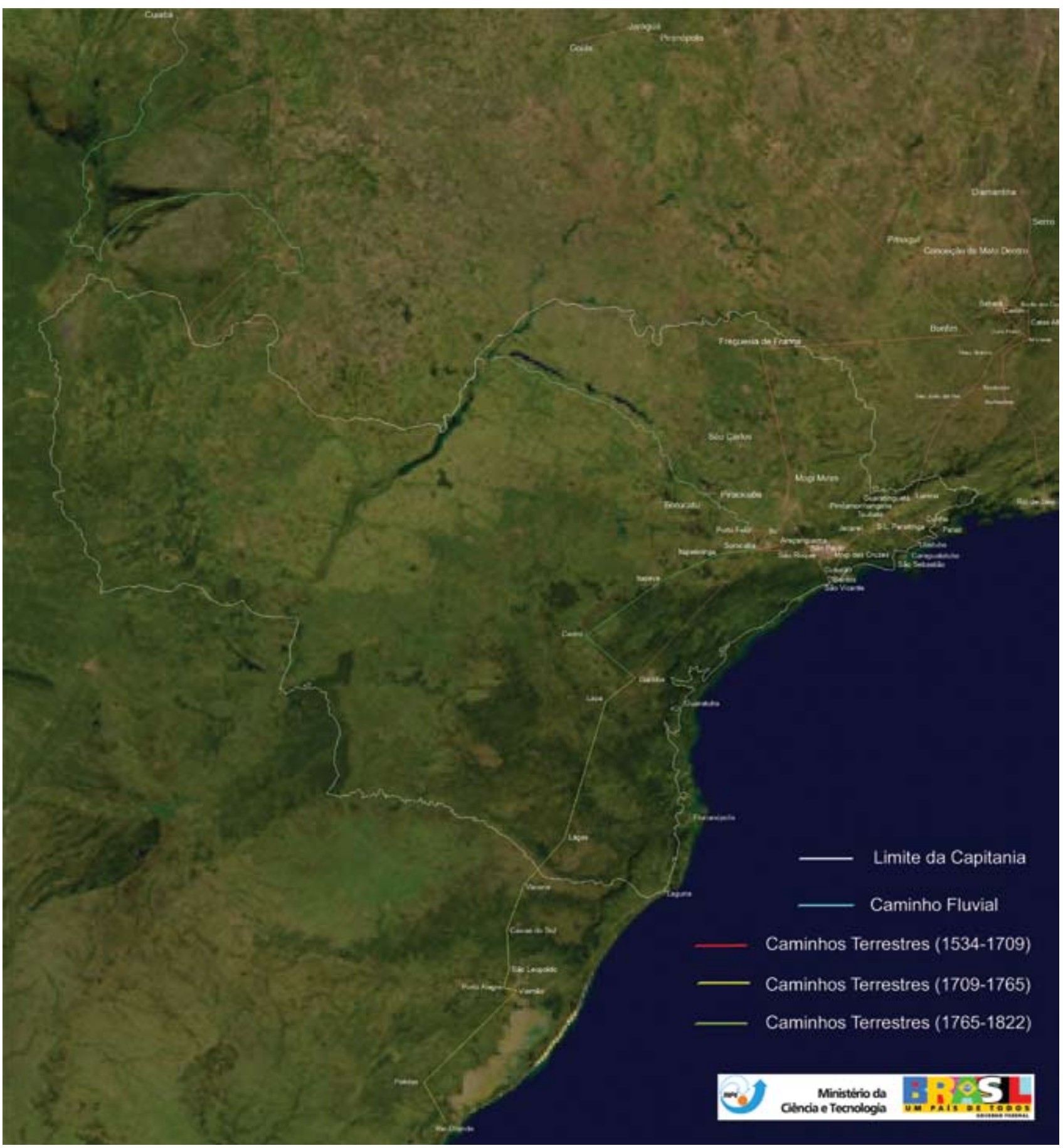

Figura 15 - Reconstituição, baseada em mapas por satélite, dos limites da rede viária e urbana da Capitania de São Paulo, entre 1765 e 1822. Instituto de Pesquisas Espaciais (INPE), São José dos Campos. 
tensões e conflitos existentes. Serializada e cotejada, essa documentação permite verificar as dificuldades de viabilizar-se um projeto de tal envergadura numa Capitania que, historicamente, devido à sua condição economicamente periférica, gozara de certa autonomia. Enormes foram as tensões entre os planos de Pombal, os do governador e os interesses da população local.

Passados dez anos, temos, em 1775, o fim da gestão do Morgado de Mateus. Taunay assim resume os seus sucessores:

Ao Morgado de Mateus sucede [... . o perverso e desiquilibrado tiranete Martin Lopes Saldanha que durante 8 anos, até 1783, flagelaria os governadores com seus desatinos e arbitrariedades. Felizmente sucedeu-lhe o bom Francisco da Cunha Menezes em, aliás, curto prazo ao qual os paulistas nos atribuíram o honroso epíteto de idade de ouro. A Menezes ao cabo de quatro anos substitui o bom marechal Frei José Raimundo Chichorro da Gama Lobo, Cavaleiro de Malta, que como Menezes, deixaria aqueles que regia a mais bela reputação a quem a cidade, assim como ao antecessor, deveu algumas iniciativas ao progresso e civilização [...]. No governo de Bernardo de Lorena, verificou-se notável surto de progresso [...] a mais notável obra [...] viria a ser o empedramento da detestável vereda frequentemente intransitável, graças a qual, pelo Caminho do Mar, São Paulo e o Planalto podiam comunicar-se com o litoral e Santos ${ }^{87}$. Tal obra devida a João da Costa Ferreira, Coronel do Real Corpo de Engenheiros e seus valorosos auxiliares trouxe imensas vantagens ao progresso paulistano ${ }^{88}$.

Chegamos ao fim de uma jornada de três séculos, com a Capitania de São Paulo apresentando contornos muito distintos, tanto dos originais como dos atuais. A reconstituição, baseada em mapa por satélite, mostra a dilatação, entre 1765 e 1822, dos limites e da rede viária e urbana em todas as direções. (Figura 15)

Se analisarmos os dados que a cartografia põe em evidência, podemos dizer, em termos de história da urbanização, que uma rede ínfima de vilas articulava um vasto território, amparada por densa rede eclesiática de capelas e freguesias, pousos e registros.

A cartografia aqui exposta documenta cada passo de um longo processo de conhecimento, dilatação, apropriação e definição do território centro-sul da América portuguesa, graças ao auxílio dos paulistas que, sempre que houve interesse, tiveram a Coroa portuguesa no seu encalço.

\section{REFERÊNCIAS}

A CAPITANIA de Itanhaém. Revista do Instituto Histórico e Geográfico de São Paulo, v. 20, 1915.

ALLIÈS, P. L'invention du territoire. Grenoble: Presses Universitaires de Grenoble, 1980.

ALMEIDA, A. de. História de Sorocaba. Sorocaba: Instituto Histórico, Geográfico e Genealógico de Sorocaba, 1969.
87. A célebre Calçada do Lorena, que, embora não carroçável, favoreceu, e muito, as trocas com o litoral, transportando, no lombo de mulas, sobretudo o açúcar do plantado.

88. Afonso de E. Taunay (1954). 
ANTONIL, A J. Cultura e opulência do Brasil [1711]. 2. ed. São Paulo: Nacional, 1966.

ARAÚJO, R. M. de. A urbanização do Mato Grosso no século XVIII: discurso e método. 2000. Tese (Doutorado em História da Arte) - Faculdade de Ciências Sociais e Humanas, Universidade Nova de Lisboa, Lisboa 2000. 2v.

AVISOS e Cartas Régias [não publicados], Lata 62, n. 420, Livro 169. São Paulo, Arquivo do Estado.

AZEVEDO, A. de. Vilas e cidades do Brasil Colonial: Ensaio de Geografia Urbana Retrospectiva. Boletim da Faculdade de Filosofia, Letras e Ciências Humanas da Universidade de São Paulo, São Paulo, 1956.

BELOTTO, H. L. Autoridade e conflito no Brasil colonial: o governo do Morgado de Mateus em São Paulo (1765-1775). 2. ed. São Paulo: Alameda, 2007.

BLAJ, I. A trama das tensões. O processo de mercantilização de São Paulo (1681-1721). São Paulo: Humanitas;Fapesp, 2002.

BLUTEAU, R. Vocabulario Portuguez e Latino... Coimbra: Collegio das Artes da Companhia de Jesus, 1712 .

BOAVENTURA, D. M. R. Urbanização em Goiás no século XVIII. 2007Tese (Doutorado em Urbanismo)- Faculdade de Arquitetura e Urbanismo, Universidade de São Paulo, 2007.

BOURDON, A. A. História de Portugal. Coimbra: Almedina, 1973.

BUENO, B. P. S. Desenho e desígnio: o Brasil dos engenheiros militares (1500-1822). 2001. Tese (Doutorado) - Faculdade de Arquitetura e Urbanismo, Universidade de São Paulo, São Paulo, 2001 (consultar versão revisada em 2003).

CAMARgo, P. F. da S. História de Santana do Parnaíba. São Paulo: Conselho de Cultura, 1971.

CASAL, A. de. Corografia Brasílica ou relação bistórico-geográfico do Reino do Brasil (1817). Belo Horizonte: Itatiaia, 1976.

COSTA, A. G. Os caminhos do ouro e a Estrada Real. Belo Horizonte: Editora da UFMG; Lisboa: Kapa, 2005.

DELSON, R. M. Novas vilas para o Brasil-Colônia: planejamento espacial e social no século XVIII. 2. ed. Brasília: Alva-Cord, 1997.

Descripção de todo o Maritimo da Terra de S. Crus chamado vulgarmente o Brazil. [c.1640]. São Paulo: Pinacoteca do Estado, Fundação Estudar, 2003.

DOCUMENTOS Interessantes para a história dos costumes de São Paulo. v. 6; 20; 23; 33; 34; 65; 67. São Paulo: Archivo do Estado, 1896.

FALCON, F. J. C. A época pombalina. São Paulo: Ática, 1982. 
ELLIS, M. Contribuição ao estudo do abastecimento das áreas mineradoras do Brasil no século XVIII. Rio de Janeiro: MEC, 1961.

FERREIRA, A. F. A acumulação capitalista em Portugal. Porto: Afrontamento, 1977.

FONSECA, C. D. Des terres aux villes de l'or. Pouvoirs et territoires au Minas Gerais (Brésil, XVIIIe siècle). Paris: Fundação Calouste Gulbenkian-Centre Culturel Calouste Gulbenkian, 2003.

GIANESELLA, R. Paisagens no tempo: vilas litorâneas paulistas. 2008. Dissertação (Mestrado em Urbanismo)- Faculdade de Arquitetura e Urbanismo, universidade de São Paulo, 2008.

HANSON, C. A. Economia e sociedade no Portugal Barroco (1668-1703). Lisboa: Dom Quixote, 1986.

HOLANDA, S. B. de. Caminhos e fronteiras. 3. ed. São Paulo: Companhia das Letras, 1994.

Movimentos de população em São Paulo no século XVIII. Revista do Instituto de Estudos Brasileiros, v. 1, p. 55-111, 1966.

LEME, Pedro T. de A. Paes. Notícias das minas de São Paulo e dos sertões da mesma Capitania. São Paulo: Comissão do IV Centenário da Cidade de São Paulo, 1954.

História da Capitania de São Vicente. Brasília: Edições do Senado Federal, 2004.

LUNA, F. V.; KLEIN, H. S. São Paulo até 1800. In: Evolução da sociedade e economia escravista de São Paulo, de 1750 a 1850. São Paulo: Edusp, 2005. p. 25-53.

MACEDO, J. B. de. A situação econômica no tempo de Pombal. 2. ed. Lisboa: Moraes,1982.

MARTINS, G. Taubaté nos seus primeiros tempos: aspectos de sua historia colonial. Taubaté: Egetal, 1973.

MARX, M. Cidade no Brasil terra de quem? São Paulo: Nobel; Edusp, 1991.

MAZZUIA, M. Jundiai através de documentos. Campinas: Palmeiras; Jundiaí: Prefeitura Municipal, 1976.

MONTEIRO, J. M. Negros da terra: índios e bandeirantes nas origens de São Paulo. São Paulo: Companhia das Letras, 1994.

MUNICÍPIOS e distritos do estado de São Paulo. São Paulo: IGC, 1995.

NEME, M. História da fundação de Piracicaba. [s/1]: João Mendes Fonseca, 1943.

PUPO, Celso Maria de Mello. Campinas, seu berço e juventude. Campinas:Academia Campinense de Letras, 1969 (Publicações da Academia Campinense de Letras, 20).

QUADRO do desmembramento territorial-administrativo dos municípios paulistas. São Paulo: IGC, 1995.

REIS FILHO, N. G. Notas sobre o urbanismo no Brasil. 1a. parte: período colonial. Cadernos de Pesquisa do Lap. São Paulo, n. 8, jun.-ago. 1995. 
Evolução urbana do Brasil (1500-1720). 2. ed. São Paulo: Pini, 2001.

São Paulo: vila, cidade e metrópole. São Paulo: Bank Boston, 2004.

REVISTA do IHGSP, v. 20, 1915.

SANTOS, F. M. dos S. Historia de Santos. São Paulo: Revista dos Tribunais, 1937. 2v.

SAIA, L. São Luís do Paraitinga. São Paulo: Secretaria da Cultura, Ciência e Tecnologia, [s.d.]

SANTOS, A. da C. Campinas, das origens ao futuro: compra e venda de terra éága e um tombamento na primeira sesmaria da Freguesia de Nossa Senbora da Conceição das Campinas do Mato Grosso de Jundiaí (1732-1992). Campinas: Editora da UNICAMP, 2002.

SCATAMACCHIA, M. C. A tradição policrômica no leste da América do Sul evidenciada pela ocupação Guarani e Tupinambá: fontes arqueológicas e etno-históricas. 1990. Tese (Doutorado em Antropologia)- Faculdade de Filosofia, Letras e Ciências Humanas, Universidade de São Paulo, São Paulo, 1990.

Seminário Cananeia tem bistória, 1. Cananeia: Prefeitura Municipal de Cananeia, 2005.

; UCHÔA, D. P. O contato euro-indígena visto através de sítios arqueológicos do estado de São Paulo. Revista de Arqueologia, São Paulo, v. 7, p. 153-173, 1993.

SIDERI, S. Comércio e poder. Lisboa: Cosmos, 1978.

SILVEIRA, W. F. da. Historia de Atibaia. São Paulo: s.c.p., 1950.

TAUNAY, A. de E. Os quatro séculos paulistanos [São Paulo em quatro séculos?]. Separata de: PREFEITURA MUNICIPAL DE SÃO PAULO. IV Centenário da Fundação da Cidade de São Paulo. São Paulo: Gráfica Municipal, 1954.

SILVA, V. A. Paulistas em movimento: bandeiras, monções e tropas. In: SETUBAL, M. A Terra Paulista. História, arte, costume. São Paulo: CENPEC/ Imprensa Oficial, 2004. p. 55-101.

ZEMELLA, M. P. O abastecimento da Capitania de Minas Gerais no século XVIII. São Paulo: USP, 1951.

ZEQUINI, A. A fundação de São Paulo e os primeiros paulistas: indígenas, europeus e mamelucos. In: SETUBAL, M. A Terra Paulista. História, arte, costume. São Paulo: CENPEC/ Imprensa Oficial, 2004. p. 29-53.

Artigo apresentado em 8/2008. Aprovado em 3/2009. 